\title{
The Early and Middle Holocene Lithic Industries of Ifri n'Etsedda (Eastern Rif, Morocco)
}

\author{
Manuel Broich (10) - Alessandro Potì • Jörg Linstädter • \\ Juan F. Gibaja • Niccolò Mazzucco • Margarita Vadillo \\ Conesa • Abdeslam Mikdad • Gerd-Christian Weniger
}

Published online: 12 March 2020

(C) The Author(s) 2020

\begin{abstract}
Archaeological research has been carried out in the Eastern Rif (Morocco) since 1995 by a collaborative Moroccan-German research team. A major topic of the project is the transition from hunting-gathering to food production and related cultural developments. Innovations such as pottery and domesticated species appeared around $7.6 \mathrm{ka}$ calBP. The cultivation of cereals and pulses is evident at that time. Two of the most important sites in the area are Ifri Oudadane and Ifri n'Etsedda. Both provide Epipaleolithic as well as Neolithic deposits. While innovative technologies such as pottery production and cultivation indicate external influences, lithic artifacts demonstrate local technological and behavioral traditions. Therefore, the study of lithic industries is crucial to understanding the nature of cultural continuity and discontinuity between the huntinggathering and agricultural populations in the Eastern Rif. Ifri n'Etsedda provides two distinct Epipaleolithic
\end{abstract}

M. Broich $(\bowtie) \cdot$ A. Potì $\cdot$ G.-C. Weniger

Institute of Prehistoric Archaeology, University of Cologne,

Weyertal 125, 50923 Cologne, Germany

e-mail: mbroich@smail.uni-koeln.de

\section{J. Linstädter}

German Archaeological Institute, Kommission für Archäologie

Außereuropäischer Kulturen (KAAK), Dürenstr. 35-37,

53173 Bonn, Germany

\section{J. F. Gibaja • N. Mazzucco}

Archaeology and Anthropology Department, Institución Milá y Fontanals (IMF-CSIC), C/Egipcíaques 15, 08001 Barcelona,

Spain deposits and thus offers the opportunity to study possible changes throughout the Epipalaeolithic and relationship to the later Early Neolithic (ENC). In combination with the earlier phases of Early Neolithic assemblages (ENA, ENB) at Ifri Oudadane, we are now in a better position to understand the development of early-to-mid Holocene lithic technology in the Eastern Rif. We show that the lithic record of Ifri n'Etsedda does not indicate any significant change in raw material supply, blank production, and tool distribution from the Early Epipaleolithic to the Early Neolithic B. Therefore, we argue for behavioral continuity from the Epipaleolithic to the Neolithic period. In contrast, the assemblages of the Early Neolithic C show changes in lithic technology.

Résumé Depuis 1995, des recherches archéologiques sont effectuées dans le Rif oriental (Maroc) par une équipe de chercheurs marocains-allemands. Un des

M. V. Conesa

Departamento de Prehistoria, Arqueología e Historia Antigua, Universitat de València, Avda. Blasco Ibáñez 28, 46010 Valencia, Spain

A. Mikdad

Institut National des Sciences de l'Archéologie et du Patrimoine (INSAP), Hay Riad, Madinat Al Irfane, Angle rues 5 et 7 , 10000 Rabat, Morocco

G.-C. Weniger

Neanderthal Museum, Talstraße 300, 40822 Mettmann, Germany 
sujets principaux du projet sera la transition des chasseurs-cueilleurs à la production alimentaire et aux développements reliés. Les innovations néolithiques telles que la poterie et les espèces domestiques apparaissent autour de $7.6 \mathrm{ka}$ calBP, à l'époque où la culture des plantes est clairement documentée pour les céréales et les légumineuses. L'Ifri Oudadane et l'Ifri n'Etsedda sont les deux sites les plus importants de la région. Les deux fournissent des couches épipaléolithiques et néolithiques. Tandis que des technologies innovantes telles que la production de la poterie ou l'agriculture témoignent des influences externes, les artefacts lithiques pourront porter la preuve de traditions technologiques et comportementales. Par conséquent, l'étude des industries lithiques est cruciale pour discuter de la continuité ou de la discontinuité de le peuplement humaine. L'Ifri n'Etsedda fournit deux couches épipaléolithiques bien séparées et nous donnera ainsi l'occasion d'étudier les changements possibles tout au long de l'ère épipaléolithique elle-même, ainsi que des couches du néolithique ancien C (ENC). Avec les assemblages du site Ifri Oudadane (ENA, ENB), le développement de la technologie lithique holocène dans le Rif oriental pourra désormais être étudié. Nous montrons que l'assemblage lithique de l'Ifri n'Etsedda n'indique aucun changement significatif en termes d'approvisionnement en matières premières, de débitage et de distribution d'outils du début de l'épipaléolithique au debut du néolithique B (ENB). Pour cette raison, nous supposons une continuité comportementale de l'épipaléolithique au néolithique. Contrairement, l'assemblage de la couche du Néolithique ancien $\mathrm{C}$ (ENC) montre les changements de la technologie lithique.

Keywords Epipaleolithic $\cdot$ Neolithic $\cdot$ Lithic technology $\cdot$ Use-wear analysis $\cdot$ Morocco $\cdot$ Holocene

\section{Introduction}

The neolithization of what is now western Mediterranean Maghreb is a complex process that can only be understood by considering a wide range of variables including the local agro-pastoral economy, technofunctional adaptions, regional diversity, chronology, and the Epipaleolithic inheritance. The understanding of the last hunter-gatherer societies and the characteristics of their socioeconomic organization are a crucial step in the study of the first Neolithic groups in this region of Africa (Manen et al. 2018). Our work contributes to this understanding by providing information on the lithic technology and economy of Holocene huntergatherers and Neolithic societies of the eastern Rif in northeast Morocco.

The rockshelter of Ifri n'Etsedda enables us to describe the lithic technology of a 4-ka long sequence spanning from the Epipaleolithic to the Late Neolithic with a short gap at the beginning of the middle Holocene. The main research objectives of this study are to characterize the lithic assemblages of the two distinct Epipaleolithic occupation phases and to understand whether these assemblages show differences or similarities. Also, the main features of the Neolithic inventories are highlighted with a focus on the late Early Neolithic (ENC), which is the main Neolithic occupation phase. The goal is to demonstrate, on the one hand, whether Epipaleolithic technical parameters are visible in the Neolithic assemblages. On the other hand, we seek to understand the degree of continuity or discontinuity between the earlier and later phases of the Early Neolithic lithic assemblages and the possible impacts of climate deterioration on the later Early Neolithic archaeological contexts (Linstädter 2016; Roberts et al. 2019; Zielhofer et al. 2019). Finally, the function of Ifri n'Etsedda, in terms of settlement and land use patterns, during the Epipaleolithic and Neolithic periods is compared with the nearby sites and assemblages along the Moulouya River (Linstädter et al. 2012): El Zafrín (Rojo Guerra et al. 2010), Ifri Oudadane (Linstädter and Kehl 2012), and the plain of Gerrouaou (Linstädter 2014).

\section{Site Setting}

The rock shelter of Ifri n'Etsedda ("Lions Cave" in the Berber language) is located at the southeastern flank of the Kebdana Mountains within the region of the Eastern Rif in northeast Morocco (Fig. 1). The shelter is at the end of a small valley at an altitude of around $300 \mathrm{~m}$ above sea level and its opening faces the east. From the opposite side of the valley, at a walking distance of about $10 \mathrm{~min}$ from the shelter, the view opens to the plain of the Moulouya River and the Beni Snassen Mountains. The easiest way to reach Ifri n'Etsedda is from the Moulouya valley, which lies about $7 \mathrm{~km}$ to the southeast as the crow flies. 


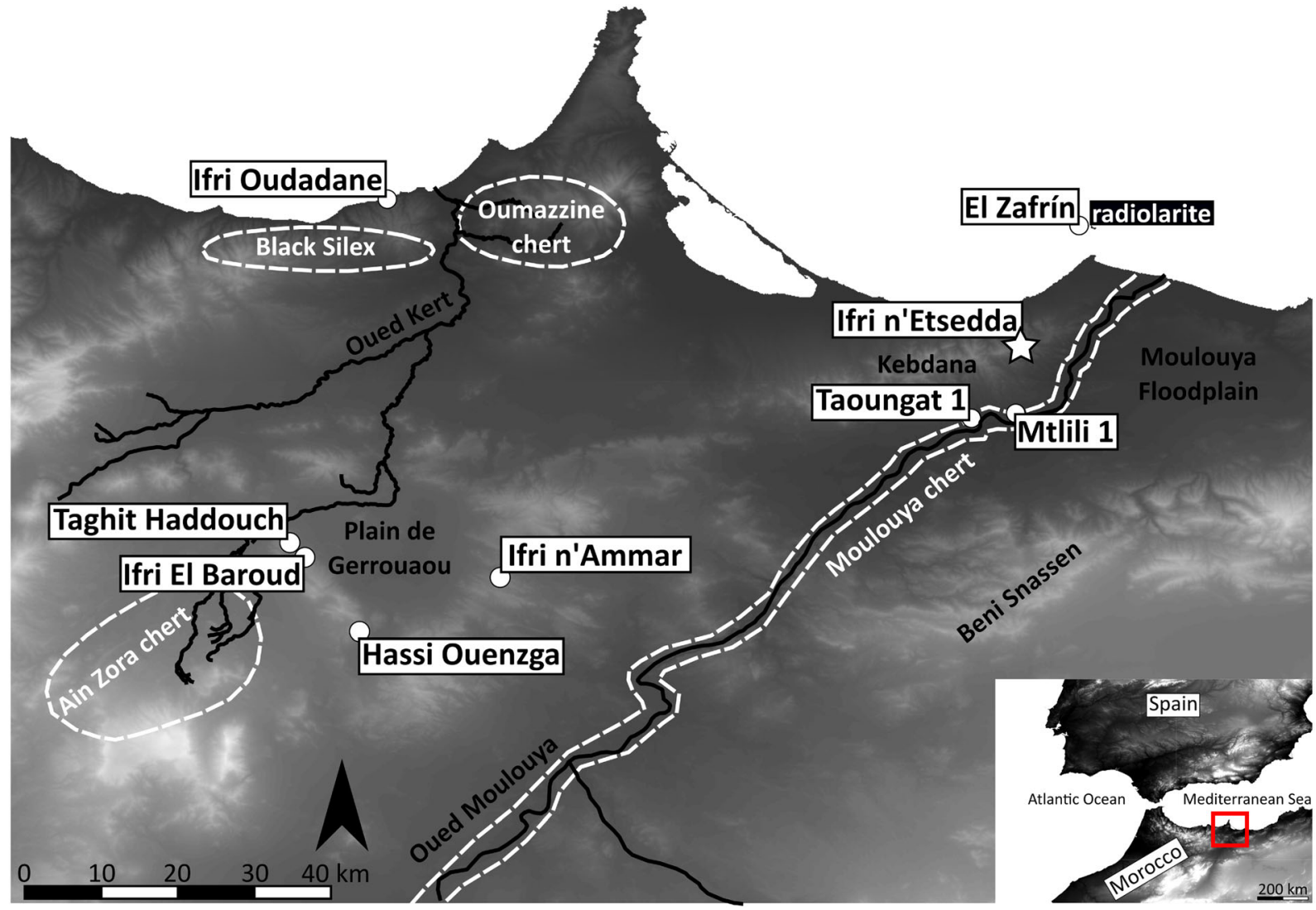

Fig. 1 Eastern Rif of Morocco showing the location of Ifri n'Etsedda and other archaeological sites (the background SRTM data originates from Jarvis et al. 2008)

The site was discovered in 2008 following archaeological surveys in the area (Ibouhouten et al. 2010; Linstädter et al. 2012). Three trenches of approximately $11 \mathrm{~m}^{2}$ were opened between 2012 and 2014, reaching a depth of $80-130 \mathrm{~cm}$. The excavated sequence consists of snail-rich deposits (Escargotière) superimposed by modern dung-rich sediment (Linstädter et al. 2016). In total, 21 radiocarbon dates combined with stratigraphical profiles allowed us to separate the excavated sequence into 12 units (cf. Linstädter et al. 2016, figure 3 ). The lowest unit, INES-1, consists of altered bedrock and thus shows no traces of human occupation. This unit is overlaid by a group of three units, which is attributed to the Epipaleolithic. Two distinct Epipaleolithic occupation phases are recognized, and these are separated by a 1000-year gap. The older "Early Epipaleolithic" (units INES-2 and INES-3) is dated to 9.8-9.6 ka calBP, whereas the younger "Late Epipaleolithic" (INES-4) is 8.8-8.6 ka calBP. The following five units belong to the Neolithic. Units INES-5, INES-6, and INES-7 correspond to the Early Neolithic A (ENA), Early Neolithic
B (ENB), and Early Neolithic C (ENC) respectively (Linstädter et al. 2018; Linstädter and Kehl 2012). The ENA unit at Ifri n'Etsedda is dated to around $7.2 \mathrm{ka}$ calBP, the ENB to $6.8-6.5 \mathrm{ka}$ calBP, and the ENC to 6.6-6.1 ka calBP. These Early Neolithic units are partly superimposed by a thin deposit (INES-8), which is attributed to the Late Neolithic. In addition, a Neolithic layer (INES-9) and a burial were documented during the 2013 and 2014 excavations. Neither has been dated, but the burial pit was dug into the Epipaleolithic sediment.

The small ceramic assemblage of Ifri n'Etsedda consists of 120 pottery units, with most sherds belonging to the ENC phase. The ENA and ENB deposits provided pottery units with Cardium decoration, which are similar to those of Ifri Oudadane (Linstädter and Wagner 2013; Linstädter et al. 2015). On the other side, herringbone motifs, which were formed by marine shells and decorations of velouté type, are present in the ENC and are similar to the decoration motifs at the nearby site of El Zafrín (Rojo Guerra et al. 2010). The Late Neolithic pottery of Ifri n'Etsedda is characterized by comb 
impressions and undecorated, polished vessels. Additionally, a mineralogical clay and temper analysis of 30 representative pottery sherds from the site has shown a chronological trend in the use of different non-local types of clay and clay sources from the ENA to the Late Neolithic (Stempfle et al. 2018).

Faunal remains at the site can be separated into two categories. The first category consists of snails. These are abundant in all archaeological units and are considered to be food remains. Similar to other archaeological sites in the region, shells of terrestrial snails from the Neolithic units show many traces of perforation (Hundsdörfer 2014; Hutterer et al. 2014). The remains of vertebrae characterize the second category. The species identification of the vertebrae bones from the Neolithic units excavated in 2012 has been completed, but work is ongoing for the other units. Various species of amphibians, reptiles, birds, and mammals are present in the faunal assemblage (Broich 2013; Hutterer pers. comm.). Among the mammalian remains, aurochs, wild boar, Barbary sheep, and gazelle are the most prevalent. There are also various reptiles (e.g., turtles) and birds such as Barbary partridge that could have served as food resources. Bones of domesticated ovicaprids are present in all Neolithic levels, and these make up to $10 \%$ of the mammalian bones depending on the level.

The pollen records show that the vegetation of the Epipaleolithic period was barely affected by human activities (Linstädter et al. 2016). At that time, a dense cover of thermo-Mediterranean evergreen oak forests points to maximum warm and humid conditions. There was no change in vegetation from the Early to the Late Epipaleolithic. These results fit the paleoenvironmental reconstruction obtained at Ifri Oudadane (Morales et al. 2013; Zapata et al. 2013). However, from the beginning of the Neolithic at around $7.2 \mathrm{ka}$ calBP, a progressive decline in arboreal pollen percentages is visible compared with the Epipaleolithic. Nevertheless, the climate was still warm and humid until the end of the ENB. The decline of arboreal pollen percentages at Ifri n'Etsedda could be due to the increasing aridification, in combination with the newly introduced mode of subsistence. For example, during the ENB, cereal pollen makes up more than $5 \%$, indicating cereal cultivation in the vicinity of the site. After the ENB phase, the progressive aridification becomes more evident. Therefore, the ENC is characterized by a disappearance of alder (Alnus) and ash (Fraxinus angustifolia) and a remarkable decline of riparian taxa but with a simultaneous increase of xerophytic elements (Artemisia) and the development of a xerothermophilous macchia. The percentage of cereal pollen drops below 3\% during the ENC. And there is no evidence of crop farming in the Late Neolithic of Ifri n'Etsedda. These dry conditions from 6.6-6.1 ka calBP are also attested at Ifri Oudadane (Zapata et al. 2013) and El Zafrín (López et al. 2010).

\section{Material and Methods}

During the three excavation campaigns at Ifri n'Etsedda, a total of 6571 chipped lithic artifacts were recovered (Table 1). In this study, lithics from the chronological units of the Early and Late Epipaleolithic, ENC, and the undated Neolithic (NEO) are considered $(n=5177)$. Due to the low number of artifacts in the stratigraphic unit INES-2, these are examined together with unit INES-3 as an early Epipaleolithic (Early EPI) assemblage. The lithic artifacts from the ENA, ENB, and the late Neolithic are not presented here in detail because of their small number. However, the study of the lithics from the nearby Ifri Oudadane provides a detailed understanding of the ENA and ENB lithic industries from the Eastern Rif of Morocco (Linstädter et al. 2015).

All artifacts with a length or width greater than $10 \mathrm{~mm}$ are included in the techno-economic and typological analyses. For each stratigraphic unit, artifacts were subdivided into five main morpho-technical categories (cores, flakes, blades/bladelets, retouched pieces, and debris/shatter) and studied singularly. Each blank was described with typometrical and technological attributes, such as dimensions, features of the dorsal face, characteristics of butt and bulb, the modality of reduction, and the relationship between flaking surface and striking platform, and raw material. All items smaller than $10 \mathrm{~mm}$ were classified as waste material, and only the raw material was determined. All tools, cores, and management flakes as well as blanks with traces of use were documented photographically. Following the procedure of Linstädter et al. (2015), the depiction of the individual artifact is combined with several photographs, and particular features are represented with standardized symbols: A filled circle or an empty circle indicates the location of a preserved or unpreserved striking platform. Furthermore, a continuous line and a 
Table 1 Number of chipped lithic artifacts per unit at Ifri n'Etsedda

\begin{tabular}{|c|c|c|c|c|c|c|c|c|c|c|c|c|}
\hline & $\begin{array}{l}\text { Early EPI } \\
\text { (INES-2) }\end{array}$ & $\begin{array}{l}\text { Early EPI } \\
\text { (INES-3) }\end{array}$ & $\begin{array}{l}\text { Late EPI } \\
\text { (INES-4) }\end{array}$ & Burial & $\begin{array}{l}\text { ENA } \\
\text { (INES-5) }\end{array}$ & $\begin{array}{l}\text { ENB } \\
\text { (INES-6) }\end{array}$ & $\begin{array}{l}\text { ENC } \\
\text { (INES-7) }\end{array}$ & $\begin{array}{l}\text { Late NEO } \\
\text { (INES-8) }\end{array}$ & $\begin{array}{l}\text { NEO } \\
\text { (INES-9) }\end{array}$ & $\begin{array}{l}\text { Sub-recent } \\
\text { (INES-10) }\end{array}$ & $\begin{array}{l}\text { Recent } \\
\text { (INES-11) }\end{array}$ & Total \\
\hline$n$ & 10 & 1624 & 2328 & 531 & 109 & 119 & 403 & 30 & 812 & 561 & 44 & 6571 \\
\hline
\end{tabular}

dash-dot line illustrate a retouched edge or macroscopically visible use-traces, respectively. A white arrow marks the direction of percussion of negatives; if a negative ends in a hinge, the letter " $\mathrm{H}$ " is printed at the tip of the arrow. Thin, short lines represent fractures.

The functional analysis focused on 163 pieces, of which 20 belong to the Early Epipaleolithic, 72 to the late Epipaleolithic, and 71 to the undated Neolithic context. These artifacts were selected after reviewing all the materials found in the different excavation campaigns. During this selection, pieces smaller than $2 \mathrm{~mm}$ (except for the retouched ones), strongly fragmented pieces, or those that were altered visually were generally ignored. It is evident that the quantitative differences in the number of pieces selected and documented from each unit will affect the diachronic comparison of the data. However, the information on the function of the lithic tools provides an approximate picture of the activities carried out at the site during the different occupational phases. The examination of the pieces has been carried out by conjugating a binocular Leica MZ16A, of magnifications between $10 \times$ and $90 \times$, and an Olympus BH2 metallographic microscope, from $50 \times$ to $400 \times$ magnification, equipped with a Canon 450D camera. In addition, photographic software (Helicon Focus v. 4.62) was used to acquire fully focused images.

\section{Results}

The techno-economic and typological analyses address the nature of preservation, sources of raw materials, the operational sequence of manufacture, and functional categories of tools.

\section{Preservation of Assemblages}

The anthropogenic snail-rich deposits of Ifri n'Etsedda are characterized by a continuous reworking of the already deposited sediment in combination with the frequent installation of new hearths (Linstädter et al. 2016). This type of sedimentation and its result, the so-called Escargotière, is common in northwest Africa and has already been documented for the late Iberomaurusian (Moser 2003; Nami and Moser 2010). In order to assess how this sedimentation process affected the preservation of the lithic artifacts and their interpretation, the influence of fire or heat as well as the number of broken artifacts was examined. The influence of fire was recorded in terms of intensity of change visible on the artifacts' surfaces (Schön 2012). Four categories were created ranging from unaffected by fire or heat (none) to high intensity of change visible because of spalling. No major differences between the assemblages are detectable (Table 2). About $50 \%$ of all lithic artifacts show traces of fire or heat, and approximately $20 \%$ are heavily affected by fire, visible through spalling and the high number of (thermal) shatters. Overall, fire or heat is not a source of bias in the proportions of the lithic artifacts at the different occupation phases.

We also recognized that the fraction of broken artifacts in an assemblage can be influenced, on the one hand, by the sedimentation processes and conditions and, on the other hand, by the reduction sequence and the manufacture of tools. In all four assemblages, about half of all flakes are completely preserved and no differences were found in the degree of preservation (Table 3). In contrast, blades are less frequently completely preserved, which could be due to the morphological features of blades, as it is easier for long and narrow elements to break. In addition, there are differences in the proportions of broken blades between the four assemblages. The number of completely preserved blades drops by about $8 \%$ from the Early to the Late Epipaleolithic, while the undated Neolithic level shows the lowest number of complete blades and the highest number of partially preserved blades. The low number of documented blades for the ENC could account for the differences in the preservation of blades. To summarize, fire or heat did not affect the preservation of lithic artifacts between the assemblages. However, differences in the proportions of broken blades may be due to lithic forms and varying modes of lithic production. These possibilities will be examined below. 
Table 2 Percentage of lithic artifacts affected by fire or heat at Ifri n'Etsedda

\begin{tabular}{lcclc}
\hline & $\begin{array}{c}\text { Early EPI } \\
(n=1634)\end{array}$ & $\begin{array}{l}\text { Late EPI } \\
(n=2328)\end{array}$ & $\begin{array}{l}\text { ENC } \\
(n=403)\end{array}$ & $\begin{array}{l}\text { NEO } \\
(n=812)\end{array}$ \\
\hline Undecidable & 1.2 & 1.5 & - & 1.4 \\
None & 52.2 & 47.6 & 52.4 & 46.3 \\
Change of color & 20.3 & 22.2 & 31.8 & 21.3 \\
Cracks & 9.3 & 8.4 & 2.7 & 9.1 \\
Spalling & 17.0 & 20.3 & 13.3 & 21.9 \\
Total & $100 \%$ & $100 \%$ & $100 \%$ & $100 \%$ \\
\hline
\end{tabular}

\section{Sources of Lithic Raw Materials}

At Ifri n'Etsedda, $99.3 \%$ of the lithic materials are made of chert from regional sources. Coarser lithologies, such as limestone and quartzite, are only represented by single artifacts, making up only $0.7 \%$ of the lithic collection. Eight different litho-groups have been documented according to petrographic features. One of these groups consists of two subgroups, giving a total of nine types of raw materials (Table 4; Fig. 1) (Götz 2016; Nami and Moser 2010; Potì 2019).

The main raw material exploited at Ifri n'Etsedda consists of fist-sized chert pebbles collected from the gravel banks of Oued Moulouya, about $7 \mathrm{~km}$ from the site (Linstädter et al. 2015). The pebbles have an irregular rounded shape with a yellowish cortex, which is heavily altered due to river transportation. This group can be divided into two subgroups of unknown primary deposition. The first heterogeneous subgroup is the so- called "Moulouya brown." Within this subgroup, we subsume brownish to grayish varieties of chert with a fine granularity, which is mostly translucent at the edges only but sometimes completely translucent. Most of the "Moulouya brown" pieces have a matt to silky appearance but this subgroup comes in many varieties and can be divided further into several subunits (Potì 2019). However, all these varieties can be found in the gravel banks of Oued Moulouya, and they have in common a good knapping quality. In contrast, the second subgroup of this raw material, the "Moulouya white", consists of chert with homogenous light gray to white color and a coarser granularity. Additionally, the "Moulouya white" is opaque and matt. Both subgroups feature inclusions and fissures. Generally, pebbles of the "Moulouya white" are larger than those of the "Moulouya brown" subgroup.

The provenance of three other raw materials is known: "Ain Zora", "Oumazzine", and radiolarite. The first one originates from the Ain Zora area, which lies roughly $120 \mathrm{~km}$ southeast of the site. There, flint nodules can be found in the local limestone formation or waste deposits. The "Ain Zora" chert has a heterogeneous and opaque matrix and is rich in particles and microfossils. Its color spectrum ranges from dark black or gray to brownish, and its fracture properties can be described as good (Potì 2019). The flint of the "Oumazzine" type occurs as pebbles in the Oued Oumazzine and its tributaries as well as in the delta of Oued Kert at a distance of about $50 \mathrm{~km}$ northwest of the site. The structure of the flint displays a fine to small granularity without any layering but has many

Table 3 Amount of complete and broken flakes and blades at Ifri n'Etsedda. The category "width incomplete" comprises of artifacts, which are completely preserved in the direction of striking but show an incomplete width

\begin{tabular}{|c|c|c|c|c|c|c|c|c|}
\hline & \multicolumn{2}{|c|}{ Early EPI } & \multicolumn{2}{|l|}{ Late EPI } & \multicolumn{2}{|l|}{$\mathrm{ENC}$} & \multicolumn{2}{|l|}{ NEO } \\
\hline & $\begin{array}{l}\text { Flake } \\
(823)\end{array}$ & $\begin{array}{l}\text { Blade } \\
(412)\end{array}$ & $\begin{array}{l}\text { Flake } \\
(1269)\end{array}$ & $\begin{array}{l}\text { Blade } \\
(524)\end{array}$ & $\begin{array}{l}\text { Flake } \\
(233)\end{array}$ & $\begin{array}{l}\text { Blade } \\
(69)\end{array}$ & $\begin{array}{l}\text { Flake } \\
(467)\end{array}$ & $\begin{array}{l}\text { Blade } \\
\text { (165) }\end{array}$ \\
\hline Complete & 47.0 & 27.9 & 41.4 & 19.8 & 47.2 & 37.7 & 45.6 & 15.2 \\
\hline Width incompl. & 3.4 & 0.5 & 4.6 & - & 6.9 & 1.4 & 2.6 & 0.6 \\
\hline Proximal & 16.0 & 29.6 & 17.1 & 34.0 & 18.9 & 29.0 & 15.0 & 33.3 \\
\hline Medial & 8.7 & 20.4 & 8.2 & 22.1 & 7.7 & 11.6 & 9.9 & 27.9 \\
\hline Distal & 21.0 & 21.6 & 23.3 & 23.7 & 18.9 & 20.3 & 21.4 & 23.0 \\
\hline Undecidable & 3.8 & - & 5.4 & 0.4 & 0.4 & - & 5.6 & - \\
\hline Total & $100 \%$ & $100 \%$ & $100 \%$ & $100 \%$ & $100 \%$ & $100 \%$ & $100 \%$ & $100 \%$ \\
\hline
\end{tabular}


Table 4 Amount and percentages of used lithic raw materials at Ifri n'Etsedda

\begin{tabular}{|c|c|c|c|c|c|c|c|c|}
\hline \multirow[b]{2}{*}{ Undecidable } & \multicolumn{2}{|c|}{ Early EPI } & \multicolumn{2}{|c|}{ Late EPI } & \multicolumn{2}{|c|}{ ENC } & \multicolumn{2}{|c|}{ NEO } \\
\hline & 206 & $(12.6 \%)$ & 295 & $(12.7 \%)$ & 5 & $(1.2 \%)$ & 54 & $(6.7 \%)$ \\
\hline Exotic Fine Red & - & - & 4 & $(0.2 \%)$ & - & - & - & - \\
\hline Exotic Fine Yellow & - & - & 1 & $(<0.1 \%)$ & - & - & - & - \\
\hline Oumazzine & - & - & - & - & - & - & 1 & $(0.1 \%)$ \\
\hline Radiolarite & 1 & $(0.1 \%)$ & - & - & - & - & - & - \\
\hline Quartzite & 2 & $(0.1 \%)$ & 1 & $(<0.1 \%)$ & - & - & 2 & $(0.2 \%)$ \\
\hline Limestone & 15 & $(0.9 \%)$ & 11 & $(0.5 \%)$ & - & - & 6 & $(0.7 \%)$ \\
\hline Ain Zora & 39 & $(2.4 \%)$ & 31 & $(1.3 \%)$ & 1 & $(0.2 \%)$ & 9 & $(1.1 \%)$ \\
\hline Moulouya white & 57 & $(3.5 \%)$ & 77 & $(3.3 \%)$ & 27 & $(6.7 \%)$ & 23 & $(2.8 \%)$ \\
\hline Moulouya brown & 1314 & $(80.4 \%)$ & 1908 & $(82.0 \%)$ & 370 & $(91.8 \%)$ & 717 & $(88.3 \%)$ \\
\hline Total & 1634 & $(100 \%)$ & 2328 & $(100 \%)$ & 403 & $(100 \%)$ & 812 & (100\%) \\
\hline
\end{tabular}

inclusions. Fissures as well as fossils can be observed. The color is mainly yellowish or reddish with many black or gray spots of different sizes. Usually the flint is opaque and matt. The fracture properties are good (Linstädter et al. 2015). The closest source of radiolarite is found on today's Chafarinas islands, in the estuary of Oued Moulouya (about $20 \mathrm{~km}$ to the northeast). This raw material was intensively used at the late Early Neolithic (ENC) site El Zafrìn (Carvalho 2010). Other sources of radiolarite are located in the Tanger-Tetuán region; therefore, the exact source of the radiolarite raw materials used at Ifri n'Etsedda remains unknown. The potential sources of all other documented raw materials at Ifri n'Etsedda are also unknown. However, limestone and quartzite can be found in the immediate surroundings of the shelter. The very fine red and yellow siliceous material defined as "Exotic Fine Red" or "Exotic Fine Yellow" does not have any correspondence in the regional chert sources and seems to come from long distances. Such exotic material has already been documented at Ifri Oudadane (Linstädter et al. 2015).

As shown in Table 4, the "Moulouya brown" subgroup, accounting for $80-90 \%$ of the lithics in Ifri n'Etsedda, is the dominant raw material in all assemblages. In sharp contrast, the "Moulouya white" comprises about $5 \%$ of the raw material in the assemblages, which could be due to its poor quality for lithic production. All other raw materials make up only a small portion of the inventories. Interestingly, the presence or absence of these raw materials differs in all the four assemblages.

\section{Operational Sequence}

The analysis of cores and debitage blanks shows the prevalence of one main reduction sequence throughout the occupational phases. However, differences in techno-typological parameters are evident. For Moulouya brown and Moulouya white, all phases of the operational sequence have been identified. Debitage was oriented towards the production of both functional flakes and blades/bladelets, though "Moulouya white" was mainly used for the production of flakes probably because of the poorer knapping properties of the raw material. Although both blanks can be classified as target products, up to $75 \%$ of the formal tools were made on blades/bladelets and about $50 \%$ of those made on flakes show remains of the cortex (Table 5). The use of flakes as blanks seems to be more opportunistic and less standardized. This observation is supported by the high number of flakes with macroscopically visible usetraces but without retouch.

After preparing the striking platform of the rounded pebbles by removing a thick cortical flake, the tool production was approached in two possible ways: the exploitation of a natural ridge that resulted in fully corticated blades or by preparing a crest (Table 6; Fig. 2: 804, 9657). The preparation of crests is not attested in the ENC assemblage, although this may be related to its small size. The larger number of cortical and partially cortical flakes in all assemblages indicates that these were primarily used to prepare the core and influence the convexities. However, the presence of cortex on most of the residual cores and the presence 
Table 5 Amount and percentage of partially cortical and non-cortical tools as well as pieces that show macroscopically use-traces but no retouch divided by blank at Ifri n'Etsedda

\begin{tabular}{|c|c|c|c|c|c|c|c|c|c|c|}
\hline \multirow[b]{2}{*}{ Tools } & \multirow[b]{2}{*}{ Flakes } & \multirow[b]{2}{*}{ Cortical } & \multicolumn{2}{|c|}{ Early EPI } & \multicolumn{2}{|c|}{ Late EPI } & \multicolumn{2}{|c|}{ ENC } & \multicolumn{2}{|c|}{ NEO } \\
\hline & & & 10 & $(11.0 \%)$ & 26 & $(16.9 \%)$ & 6 & $(33.3 \%)$ & 8 & $(20.0 \%)$ \\
\hline & & Non-cortical & 14 & $(15.4 \%)$ & 12 & $(7.8 \%)$ & 1 & $(6.7 \%)$ & 5 & $(12.5 \%)$ \\
\hline & Blades/bladelets & Cortical & 9 & $(9.9 \%)$ & 23 & $(14.9 \%)$ & 3 & $(20.0 \%)$ & 6 & $(15.0 \%)$ \\
\hline & & Non-cortical & 58 & $(63.7 \%)$ & 93 & $(60.4 \%)$ & 6 & $(40.0 \%)$ & 21 & $(52.5 \%)$ \\
\hline Total & & & 91 & $(100 \%)$ & 154 & $(100 \%)$ & 15 & $(100 \%)$ & 40 & $(100 \%)$ \\
\hline \multirow[t]{4}{*}{ Use-trace } & Flakes & Cortical & 14 & $(19.7 \%)$ & 22 & $(25.6 \%)$ & 4 & $(44.4 \%)$ & 8 & $(26.7 \%)$ \\
\hline & & Non-cortical & 16 & $(22.5 \%)$ & 22 & $(25.6 \%)$ & 1 & $(11.1 \%)$ & 6 & $(20.0 \%)$ \\
\hline & Blades/bladelets & Cortical & 11 & $(15.5 \%)$ & 11 & $(12.8 \%)$ & 3 & $(33.3 \%)$ & 10 & $(33.3 \%)$ \\
\hline & & Non-cortical & 30 & $(42.3 \%)$ & 31 & $(36.0 \%)$ & 1 & $(11.1 \%)$ & 6 & $(20.0 \%)$ \\
\hline Total & & & 71 & $(100 \%)$ & 86 & $(100 \%)$ & 9 & $(100 \%)$ & 30 & (100\%) \\
\hline
\end{tabular}

of items with natural butts indicates that, in some cases, surfaces were left corticated throughout the debitage (Fig. 3). Blades show in comparison less frequent traces of cortex and are rarely fully corticated. Nevertheless, a slight decrease in the number of non-cortical blades is recognizable within the Neolithic assemblages. About $20 \%$ of the four assemblages consist of thermal shatters, i.e., artifacts that could not be classified because of firerelated alterations (Table 6).

Most of the cores documented at Ifri n'Etsedda are flake production cores. Within the Epipaleolithic assemblages, approximately $50 \%$ of these cores show an irregular reduction, such as the presence of several unrelated striking platforms and debitage surfaces. Apart from this, a unidirectional mode of reduction of flake cores is common in all assemblages. On the other side, bidirectional exploitation of flake cores is only in evidence for the Epipaleolithic assemblages, while orthogonal reduction is solely attested in the ENC. In comparison, blade/bladelet cores exhibit mostly a unidirectional reduction, and for the Neolithic assemblages, this is the only mode of reduction. Nonetheless, bidirectional and irregular modes of exploitation of blade/bladelet cores are evident for the Early and Late Epipaleolithic.

When these observations are compared with the orientation of the negatives on blanks, we have the following results (Fig. 4). On the one side, blades/bladelets show a unidirectional orientation of the negatives in most cases. On the other side, the orientation of the negatives on flakes is more variable. Interestingly, orthogonally oriented negatives on flakes and blades do not only appear in the ENC assemblage but also in all other inventories, though they are more frequent in the ENC. These characteristics resulted from the transformation of blade/bladelet cores into flake cores. That is, after the exploitation of blade/bladelet cores, when the core was not suitable anymore for obtaining blades/ bladelets, these cores were used as sources of flakes. Accordingly, several flake cores show the remains of their former use as a blade/bladelet core (Fig. 2: 8790).

Several core maintenance products are evident in all the inventories (Table 6). Three core tablets are indicative of the installation of new striking platforms, and they were used to improve the angle between striking platform and debitage surface (Fig. 5: 10651). Core flanks (debordant elements) and pieces with dorsal hinges document the maintenance of the lateral convexities and the regeneration of the debitage surface by removing knapping accidents. Some thick outrepassé elements may have served to maintain the longitudinal convexities or to remove irregular portions of the volume (Fig. 5: 162). Neo-crests and partial neo-crests are documented for the Early and Late Epipaleolithic and the undated Neolithic; they show the need to reshape the lateral and longitudinal convexities during reduction. In addition, there are core preparation flakes that were, for example, obtained at the crest between debitage surface and striking platform to reorientate the core and mark a change in striking platform and/or the debitage surface (Fig. 5: 1764), a procedure that already has been observed at Ifri Oudadane (Linstädter et al. 2015).

The preparation of the knapping surface was limited, as indicated by the high frequency of flat butts and the very low number of facetted ones (Fig. 3). Overhang 
Table 6 Amount and percentage of blank and core types, debris, and core maintenance products at Ifri n'Etsedda divided according to the respective occupation phases

\begin{tabular}{|c|c|c|c|c|c|c|c|c|c|c|}
\hline & & & Early & & Late $\mathrm{E}$ & & ENC & & NEO & \\
\hline Production & Flake & Cortical flakes & 72 & $(4.4 \%)$ & 80 & $(3.4 \%)$ & 43 & $(10.7 \%)$ & 41 & $(5.0 \%)$ \\
\hline & & Partially cortical flakes & 388 & $(23.7 \%)$ & 636 & $(27.3 \%)$ & 120 & $(29.8 \%)$ & 258 & $(31.8 \%)$ \\
\hline & & Non-cortical flakes & 363 & $(22.2 \%)$ & 553 & $(23.8 \%)$ & 70 & $(17.4 \%)$ & 168 & $(20.7 \%)$ \\
\hline & Blade/bladeltes & Cortical blade & 5 & $(0.3 \%)$ & 6 & $(0.3 \%)$ & - & - & 3 & $(0.4 \%)$ \\
\hline & & Partially cortical blades & 109 & $(6.7 \%)$ & 172 & $(7.4 \%)$ & 38 & $(9.4 \%)$ & 67 & $(8.3 \%)$ \\
\hline & & Non-cortical blade & 298 & $(18.2 \%)$ & 346 & $(14.9 \%)$ & 31 & $(7.7 \%)$ & 95 & $(11.7 \%)$ \\
\hline Cores & Flake & Unipolar & 10 & $(0.6 \%)$ & 11 & $(0.5 \%)$ & 13 & $(3.2 \%)$ & 8 & $(1.0 \%)$ \\
\hline & cores & Bidirectional & 4 & $(0.2 \%)$ & 1 & $(<0.1 \%)$ & - & - & - & - \\
\hline & & Orthogonal & - & - & - & - & 5 & $(1.2 \%)$ & - & - \\
\hline & & Multidirectional & - & - & - & - & 1 & $(0.2 \%)$ & - & - \\
\hline & & Irregular & 15 & $(0.9 \%)$ & 21 & $(0.9 \%)$ & 5 & $(1.2 \%)$ & 6 & $(0.7 \%)$ \\
\hline & & Undecidable & 1 & $(0.1 \%)$ & - & - & 2 & $(0.5 \%)$ & - & - \\
\hline & Blade/bladelet cores & Unipolar & 11 & $(0.7 \%)$ & 8 & $(0.3 \%)$ & 4 & $(1.0 \%)$ & 3 & $(0.4 \%)$ \\
\hline & & Bidirectional & 1 & $(0.1 \%)$ & 4 & $(0.2 \%)$ & - & - & - & - \\
\hline & & Irregular & 1 & $(0.1 \%)$ & 4 & $(0.2 \%)$ & - & - & - & - \\
\hline & & Undecidable & 2 & $(0.1 \%)$ & - & - & - & - & - & - \\
\hline & Indet. & Unipolar & - & - & 1 & $(<0.1 \%)$ & 1 & $(0.2 \%)$ & - & - \\
\hline & & Irregular & 1 & $(0.1 \%)$ & 1 & $(<0.1 \%)$ & - & - & - & - \\
\hline & & Undecidable & 2 & $(0.1 \%)$ & 5 & $(0.2 \%)$ & - & - & 3 & $(0.4 \%)$ \\
\hline Other & & Shatter/debris & 306 & $(18.7 \%)$ & 468 & $(20.1 \%)$ & 69 & $(17.1 \%)$ & 157 & $(19.3 \%)$ \\
\hline & & Microburin & 2 & $(0.1 \%)$ & - & - & - & - & - & - \\
\hline & & Burin spall & 4 & $(0.2 \%)$ & 3 & $(0.1 \%)$ & - & - & 2 & - \\
\hline & & Tested piece & - & - & 1 & $(<0.1 \%)$ & - & - & - & - \\
\hline & & Untested piece & 39 & $(2.4 \%)$ & - & - & 1 & $(0.2 \%)$ & 1 & $(0.1 \%)$ \\
\hline & & Undecidable & - & - & 7 & $(0.3 \%)$ & 1 & $(0.2 \%)$ & - & - \\
\hline Total & & & 1634 & $(100 \%)$ & 2328 & (100\%) & 403 & $(100 \%)$ & 812 & (100\%) \\
\hline Core maint & lance products & Core tablets & - & - & 1 & $(1.0 \%)$ & 1 & $(5.0 \%)$ & 1 & $(2.1 \%)$ \\
\hline & & Core flanks & 18 & $(23.4 \%)$ & 39 & $(39.0 \%)$ & 6 & $(30.0 \%)$ & 22 & $(45.8 \%)$ \\
\hline & & Crested blades & 8 & $(10.4 \%)$ & 8 & $(8.0 \%)$ & - & - & 2 & $(4.2 \%)$ \\
\hline & & Neo-crests & 11 & $(14.3 \%)$ & 7 & $(7.0 \%)$ & - & - & 2 & $(4.2 \%)$ \\
\hline & & Outrepassé & 16 & $(20.8 \%)$ & 16 & $(16.0 \%)$ & 11 & $(55.0 \%)$ & 8 & $(16.7 \%)$ \\
\hline & & Preparation flakes & 24 & $(31.2 \%)$ & 29 & $(29.0 \%)$ & 2 & $(10.0 \%)$ & 13 & $(27.1 \%)$ \\
\hline Total & & & 77 & $(100 \%)$ & 100 & $(100 \%)$ & 20 & $(100 \%)$ & 48 & $(100 \%)$ \\
\hline
\end{tabular}

abrasion and smaller and more regular butt forms are more common for blades/bladelets than flakes. In contrast, the occurrence of lips is equally distributed among the blades/bladelets and flakes. Hence, it is likely that for core preparation and core maintenance (involving removal of flakes), a hard hammer-stone was used, whereas for the removal of blades/bladelets, a soft hammer-stone (pierre tendre) or antler was preferred (Floss 2012b; Pelegrin 2000). Interestingly, regardless of the type of blank, flakes and blades/bladelets from the ENC assemblage feature fewer dorsal reductions and more lips, when compared with the other inventories. In order to evaluate the extent to which this is related to a change in knapping techniques, further investigations are necessary since it is also conceivable that this difference may be due to the low number of artifacts attributed to the ENC.

The measurements of completely preserved blanks show that approximately $75 \%$ of all artifacts, which are 


\section{Early Epipalaeolithic}
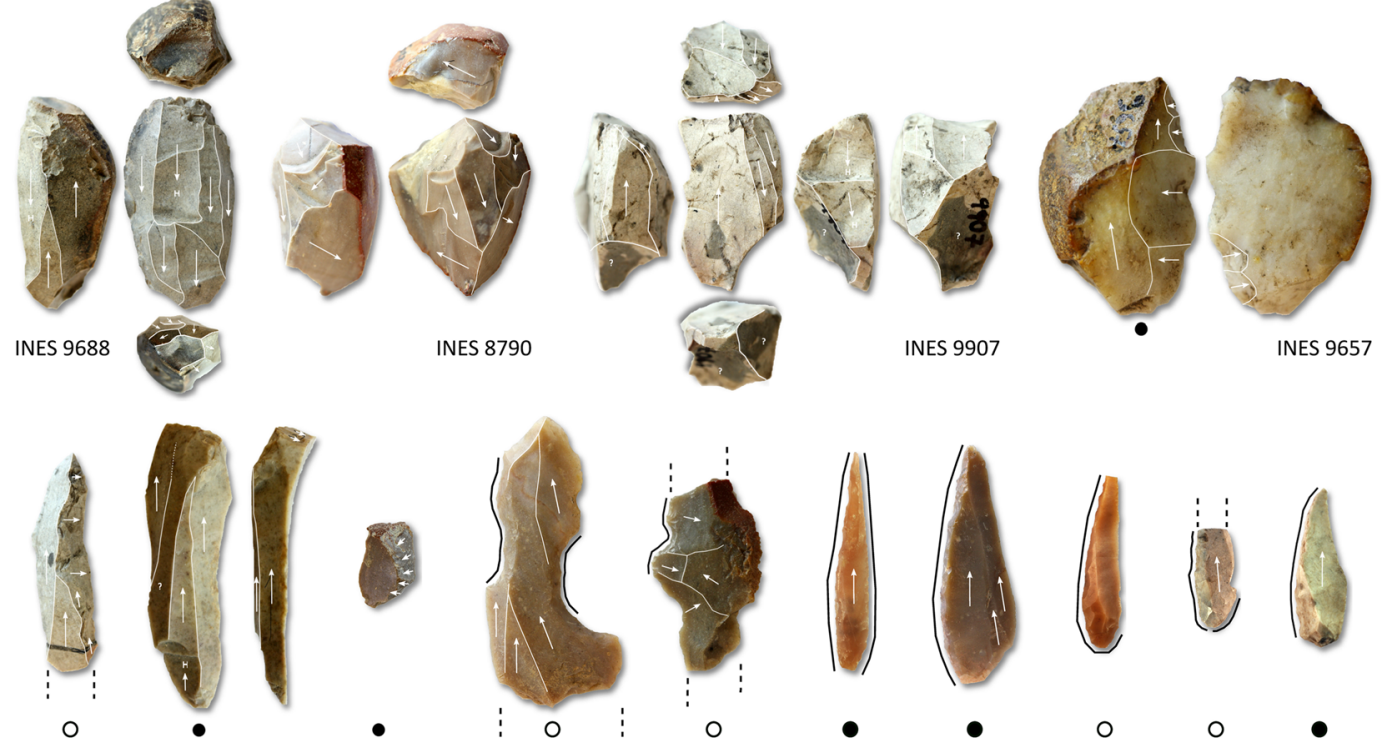

INES 9658 INES $7679 \quad$ INES $9905 \quad$ INES 9035

INES 8946

INES 1023

INES 9863 INES 3370 INES 3721 INES 2899

\section{Late Epipalaeolithic}
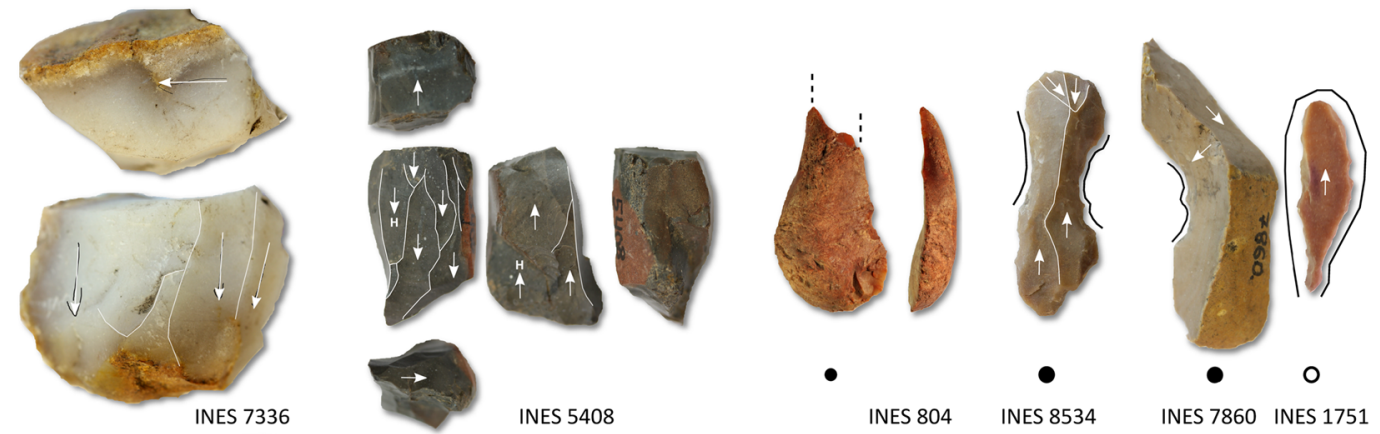

INES $804 \quad$ INES 8534

INES 7860 INES 1751
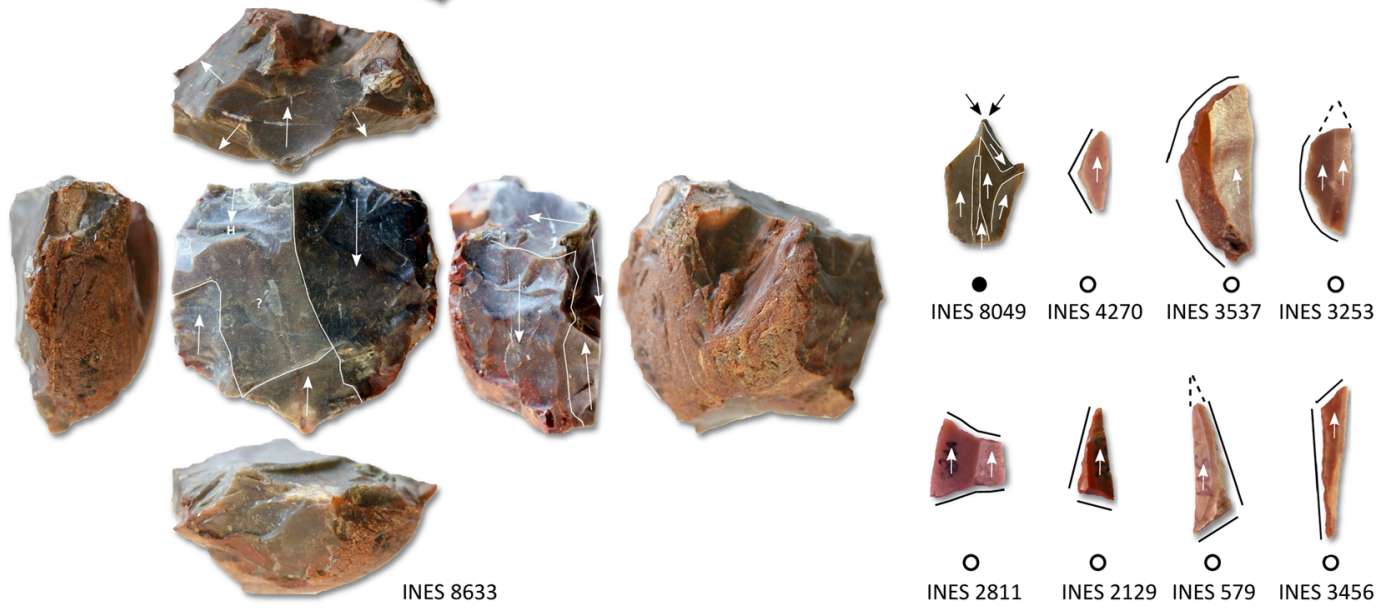

INES 2811 INES 2129 INES 579 INES 3456

at least twice as long as they are wide, fall into the category of bladelets according to Tixier (1963). No statistically relevant differences can be observed for the dimensions of blades/bladelets, although those from the 
Fig. 2 Selected artifacts from the Early and Late Epipalaeolithic layers of Ifri n'Etsedda. 9688: bladelet core, unidirectional; 8790: flake core, bidirectional, former used as bladelet core; 9907: bladelet core, possible bidirectional, raw material undecidable; 9657: nucleus on flake, Moulouya white, crest preparation visible; 9658: neo-crest; 7679: outrepassé; 9905: partial core tablet; 9035: notched bladelet; 8946: notched piece; 1023: perforator; 9863 : backed bladelet with impact fracture (Tixier: 56); 3370: backed bladelet (Tixier: 46); 3721: backed bladelet (Tixier: 46), raw material undecidable; 2899: backed bladelet (Tixier: 56), raw material undecidable; 7336: blade core, unipolar, Moulouya white; 5408: nucleus with bidirectional reduction; 804: opening blade using natural ridge; 8534: notched blade (Tixier: 76); 7860: denticulated blade (Tixier: 77); 1751: perforator (Tixier: 13); 8633 : flake core, possible bidirectional; 8049: nucleus on flake, flake is obtained from a blade core with bidirectional blade removals visible; 4270: triangle (Tixier: 89); 3537: lunate (Tixier: 82); 3253: lunate (Tixier: 82); 2811: trapeze (Tixier: 82); 2129: triangle (Tixier: 90), exotic fine red; 579: triangle (Tixier: 95); 3456 : triangle (Tixier: 97)

Epipaleolithic assemblages seem to be slightly longer than those from the Neolithic assemblages (Fig. 6). The width of blades/bladelets from all four assemblages is especially standardized with a mean width of $9.85 \mathrm{~mm}$, $10.03 \mathrm{~mm}, 9.83 \mathrm{~mm}$, and $10.25 \mathrm{~mm}$ for the Early EPI, Late EPI, ENC, and NEO, respectively. The interquartile range of the width of blades for the Early and Late EPI as well as the NEO lies within 7-13 $\mathrm{mm}$, while the range for the ENC inventory is slightly narrower, $8-12 \mathrm{~mm}$. On the contrary, the dimensions of flakes are more variable, and flakes from the Neolithic assemblages seem to be longer and wider. This is particularly evident for the ENC flakes, with a mean length of $19.53 \mathrm{~mm}$ and a mean width of $18.63 \mathrm{~mm}$, compared with a mean length of $17.00,17.83$, and $18.07 \mathrm{~mm}$ and a mean width of $14.33,14.95$, and $16.10 \mathrm{~mm}$ for the Early EPI, Late EPI, and NEO inventories, respectively.

\section{Tools}

The recorded toolkits of the Early and Late Epipaleolithic as well as the late Early Neolithic $\mathrm{C}$ and the undated Neolithic are presented in Fig. 7. In order to improve the comparison with the other sites of the region, retouched items are classified using both a general nomenclature (Sheppard 2016) and the typological list of J. Tixier (1963). About 13-22\% of all blades/ bladelets and $3-5 \%$ of all flakes were transformed into formal tools, which support the hypothesis that the main target products were elongated elements. As can be seen in Fig. 7, about $50 \%$ of all tools made on blades/
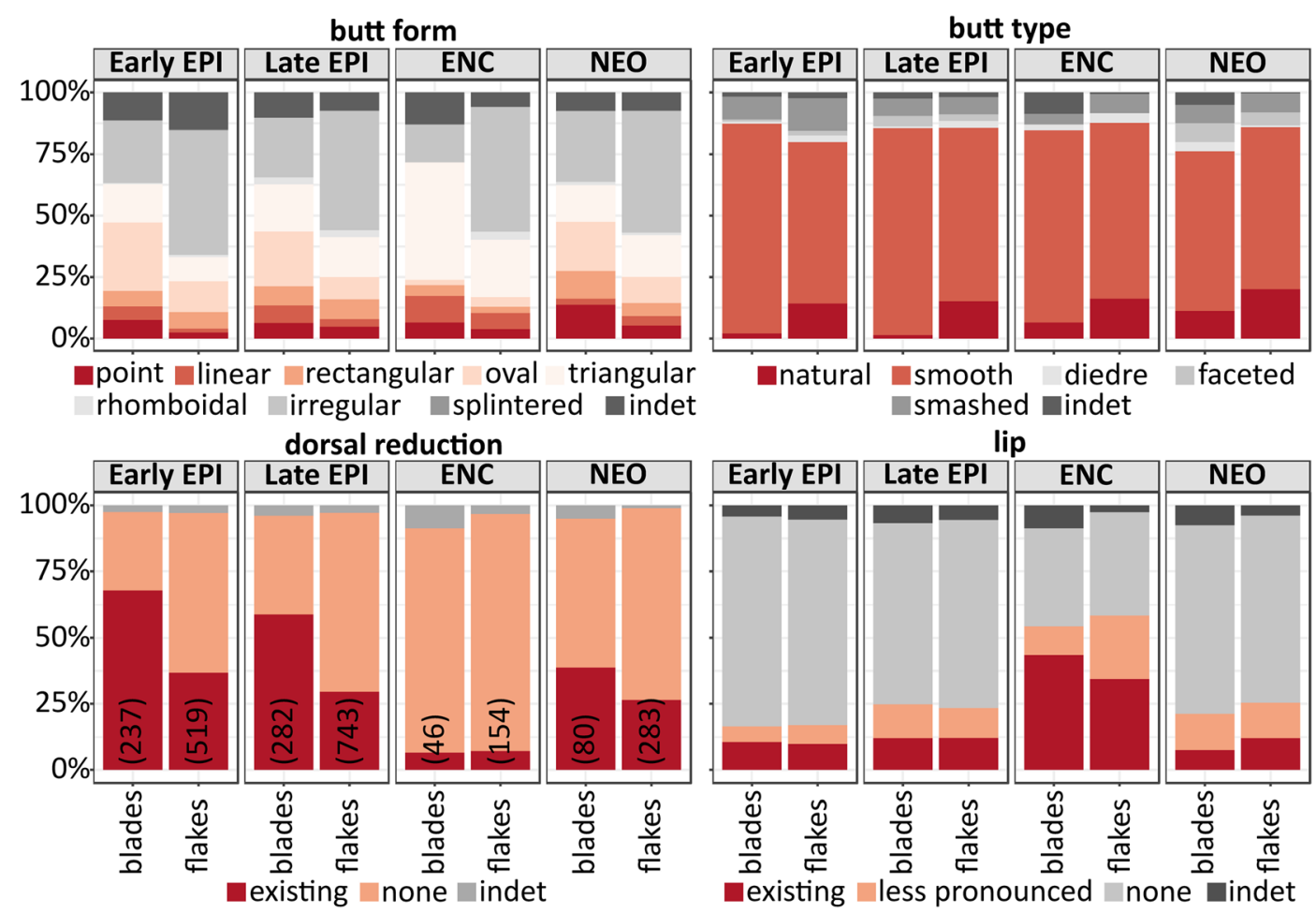

Fig. 3 Characteristics of blades/bladelets and flakes at Ifri n'Etsedda (absolute numbers are given in parenthesis on the bottom left bar plot) 
Fig. 4 Orientation of negatives on blanks from Ifri n'Etsedda (the absolute number of the considered artifacts is given in the parentheses)

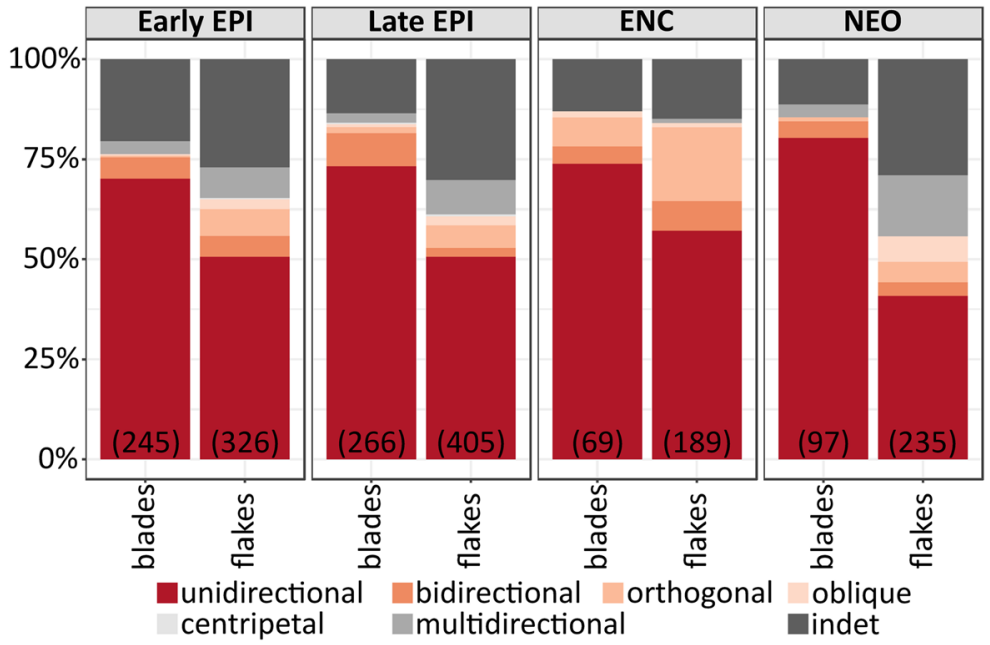

bladelets are implements related to armatures. Most of the implements are backed bladelets (Fig. 2: 9863, 3370,
3721, 2899; Fig. 5: 5700) followed by geometric microliths (Fig. 2: 4270-3456; Fig. 5: 10660-10560,
Fig. 5 Selected artifacts from the Late Early Neolithic (ENC) and the undated Neolithic layer of Ifri n'Etsedda. 10651: core tablet; 10628: retouched blade (Tixier: 105); 10660: lunate (Tixier: 83 or 82); 10664: trapeze (Tixier: 83); 10900: trapeze (Tixier: 83); 10560: lunate (Tixier: 82); 5315: blade core; 6073: flake core, Moulouya white; 6113: bladelet core; 35: outrepassé; 162: outrepassé; 1764: reorientation flake; 2495 crested blade; 5527 : scrapper (Tixier 2), Oumazzine; 5049: notched blade (Tixier 76); 6050: denticulated blade (Tixier 77); 5700: backed bladelet (Tixier 49); 3158: triangle (Tixier 90)

\section{Early Neolithic C (ENC)}
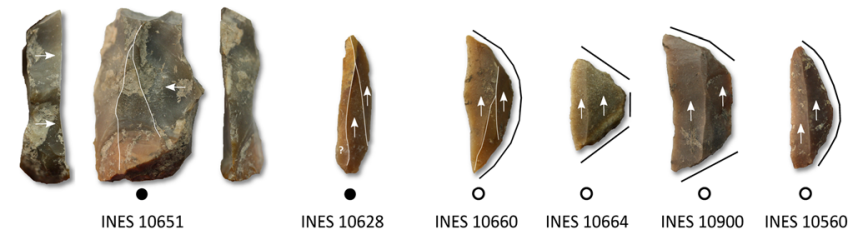

INES 10900 INES 10560

\section{Neolithic (NEO)}

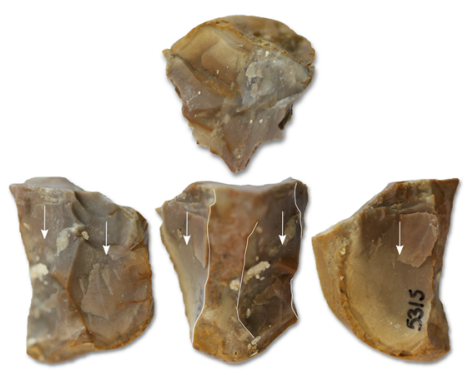

INES 5315

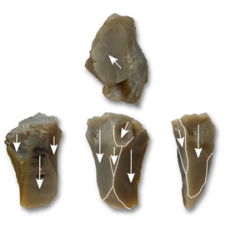

INES 6113
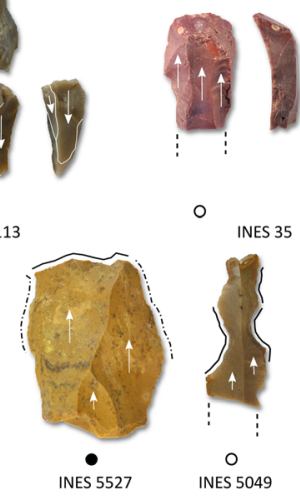

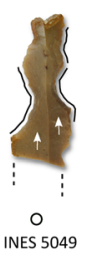

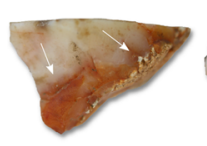
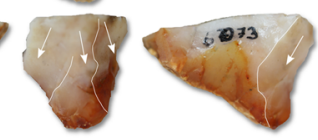

INES 6073

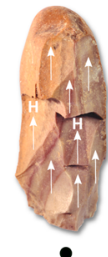

-
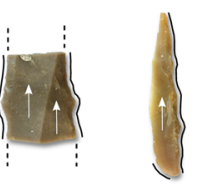

INES 162

INES 1764

INES 2495

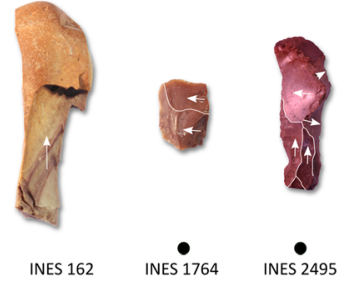


Fig. 6 Length vs. width of completely preserved flakes and blades/bladelets and flake and blade cores at Ifri n'Etsedda. (The number of artifacts are for flakes (323, 438, 99, 190), blades (100, $90,24,23)$, flake cores $(21,28$, $17,10)$, blade cores $(12,14,1,3)$ in Early EPI, Late EPI, ENC, and NEO, respectively)

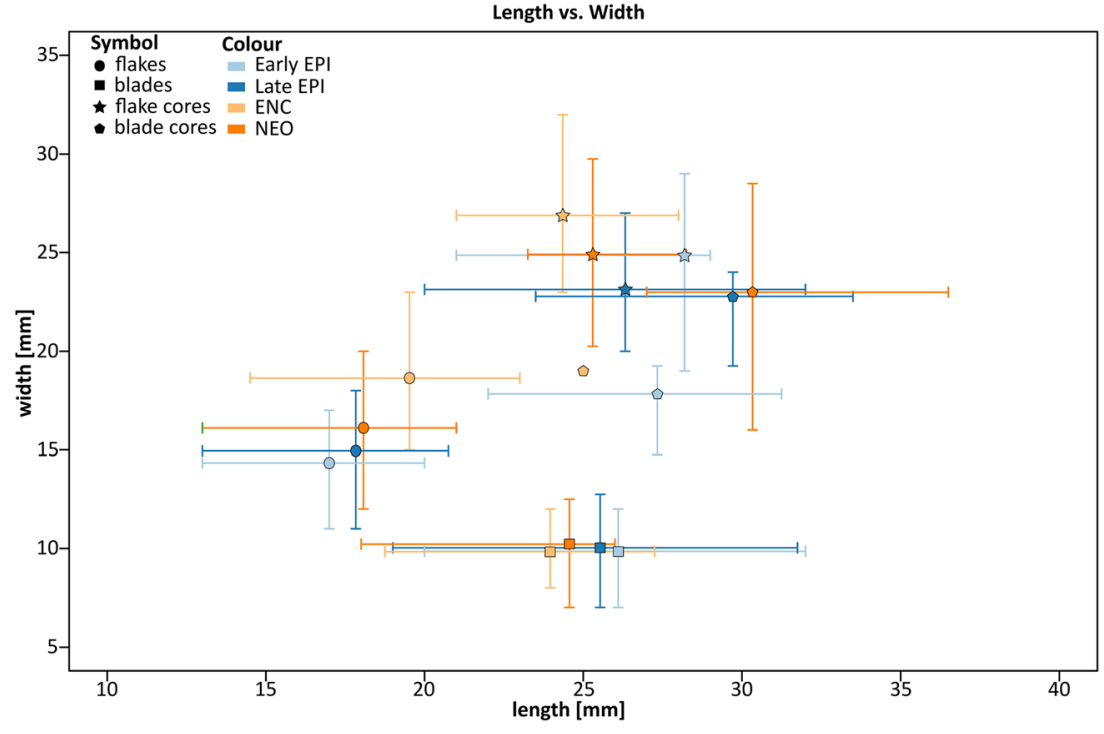

3158). Interestingly, the Late Epipaleolithic features the greatest variation of microlith types and the highest number. Notched (Fig. 2: 9035, 8534; Fig. 5: 5049) or denticulated (Fig. 2: 7860; Fig. 5: 6050) blades account for $20 \%$ of the tools. The rest of the toolkits were comprised of three kinds of tools.
The first kind consisted of perforators, which were probably used to create holes in organic materials like bone and leather (Floss 2012a) or used in the process of ostrich egg shell bead production, evident at Ifri n'Etsedda (R. Hutterer and S. Lehnig, pers. comm.). The second kind of tool, end and lateral retouched blades, occurs in the Early

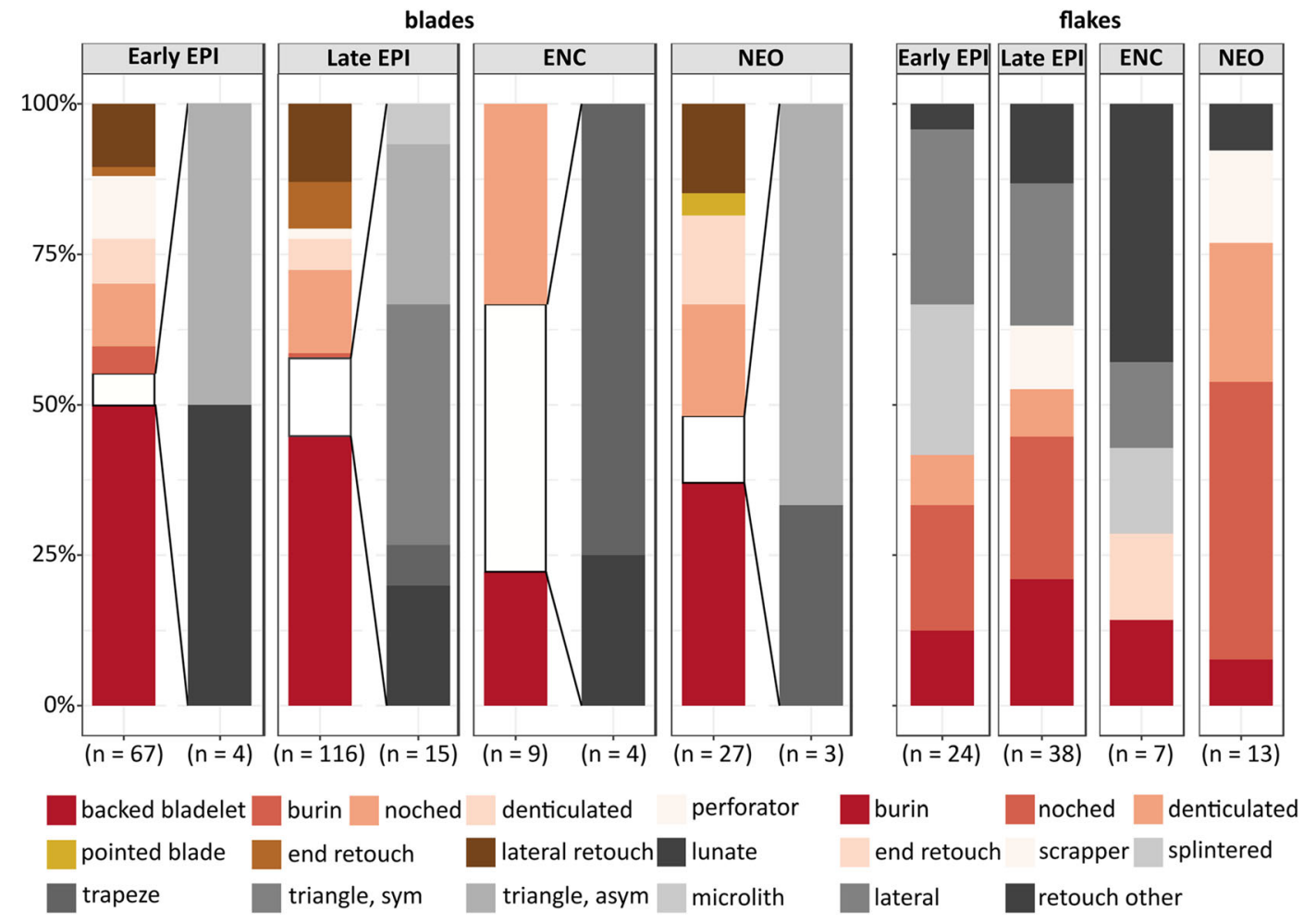

Fig. 7 Percentage of tool types at Ifri n'Etsedda separated by blank 
and Late Epipaleolithic and the undated Neolithic assemblages. The end retouch was probably applied to the blade to shorten it or in the context of hafting (Hahn 1993). Likewise, the attachment of lateral retouches to blades can be viewed in the same context (Pasda 2012). The third group consisted of tools made on flakes. These are less frequent and seem to be more variable in the sense that no tool type dominates the toolkit. In addition, no differences between the assemblages are recognizable (Fig. 7). As in the case of tools made on blades/bladelets, flakes were also transformed into burins, notched and denticulated pieces, as well as pieces with a lateral or end retouch. New tool types are endscrapers and splintered pieces. The function of splintered pieces is discussed thoroughly in the literature (e.g., Le Brun-Ricalens 2012) and can be summarized as the use of cores or as intermediate pieces, like a wedge or a chisel, in the process of splitting a workpiece or preparing a surface. However, in the present case, these splintered flakes were likely used as intermediate pieces since there are no end products in the assemblage suitable for the knapping process.

Table 7 shows the recorded Tixier-types for each of the four assemblages. Eighty Tixier-type tools were recorded for the Early Epipaleolithic, 124 for Late Epipaleolithic, 15 for ENC, and 36 for the undated Neolithic. In total, 48 different Tixier-types were recorded. The Late Epipaleolithic, with 35 different types, shows the highest variability and stands out in the number of different types of backed bladelets and geometric microliths. On the contrary, microburins are only attested for the Early Epipaleolithic inventory. Since the toolkits of the ENC and the undated Neolithic are comparatively small, these cannot be compared with the Epipaleolithic assemblages. However, three Tixier-types, one type of endscraper (Tixier-type 2), and two types of backed bladelets (Tixier-types 49 and 62), are only present in the Neolithic assemblages.

\section{Use-Wear Analysis}

The lithics selected for functional analysis show a good state of preservation and no concretions are present on their surfaces. Nevertheless, some pieces show light alteration due to friction with sediment or to some indeterminable chemical reaction but this did not affect the functional determination. It was only on a few pieces that use-wear analysis was not possible because of patina or substantial alteration by fire. For the functional analysis, different macro- and microscopic traces like scars, rounding, striations, and micropolish were observed and evaluated together. Based on these traces, the performed motion of the tool (kinematics) and the worked material are determined (Gassin 1996; Gibaja 2003; González Urquijo and Ibáñez Estévez 1994; Plisson 1985; Van Gijn 1989).

\section{Use-Wear Analysis for the Early Epipaleolithic Lithics}

Only 20 artifacts from this occupation phase were selected for use-wear analysis. Out of these, seven pieces were not used, five pieces could not be analyzed, four showed use-traces, and the remaining four pieces did not show diagnostic criteria whether they were used or not. Of the four pieces with use-traces, one is a blade without retouch and had been used for butchering, evident by small intermittent scars on both sides of the edge and small areas of compact polishing resulting from contact with the skeletal part of the animal. One small fragment of a backed bladelet showed impact fractures as a result of its use as a projectile. For the two other pieces, one small fragmented blade with two zones of use-traces and one flake without retouch, it was only possible to determine that they were used to process an unknown semi-hard material indicated by the morphology and quantity of the scars, by the shape and angle of the edge, and by the characteristics of the polishing. The two other backed bladelets could not be analyzed with confidence because of fractures generated by thermal alterations. However, we conjecture that they were possibly used as projectiles.

\section{Use-Wear Analysis for the Late Epipaleolithic Lithics}

Of the 72 analyzed pieces from this occupation level, 16 pieces did not show use-traces, eight could not be analyzed, 28 showed traces of use, and for 20 artifacts, it was impossible to decide whether they have been used or not because diagnostic criteria were missing. In general, the documented tools were used for a wide range of activities, especially those related to the acquisition, processing, and treatment of animal materials (Fig. 8). Thus, there are pieces used as projectiles (Fig. 9: 1) as well as pieces used for cutting meat or treating hide or bones. The processing of those materials often generates very diagnostic traces. Hide usually causes a very pronounced rounding of the edge, and bone produces many overlapping scars and a very compact polish. Compared with these tools, there are only two pieces with 
Table 7 Recorded Tixier-Types at Ifri n'Etsedda

\begin{tabular}{|c|c|c|c|c|c|c|c|c|c|}
\hline \multirow{2}{*}{$\begin{array}{l}\text { Tixier type } \mathrm{n}^{\circ} \\
\text { Endscraper }\end{array}$} & \multirow[b]{2}{*}{1} & \multicolumn{2}{|c|}{ Early EPI } & \multicolumn{2}{|c|}{ Late EPI } & \multicolumn{2}{|c|}{$\mathrm{ENC}$} & \multicolumn{2}{|c|}{ NEO } \\
\hline & & - & - & 1 & $(0.8 \%)$ & - & - & 1 & $(2.8 \%)$ \\
\hline & 2 & - & - & - & - & - & - & 1 & $(2.8 \%)$ \\
\hline & 5 & - & - & 1 & $(0.8 \%)$ & - & - & - & - \\
\hline \multirow[t]{2}{*}{ Perforator } & 13 & 2 & $(2.5 \%)$ & 2 & $(1.6 \%)$ & - & - & - & - \\
\hline & 16 & 3 & $(3.8 \%)$ & - & - & - & - & - & - \\
\hline \multirow[t]{6}{*}{ Burin } & 17 & 1 & $(1.3 \%)$ & - & - & 1 & $(6.7 \%)$ & - & - \\
\hline & 18 & - & - & 1 & $(0.8 \%)$ & - & - & - & - \\
\hline & 20 & - & - & 1 & $(0.8 \%)$ & - & - & - & - \\
\hline & 22 & - & - & 1 & $(0.8 \%)$ & - & - & - & - \\
\hline & 28 & 1 & $(1.3 \%)$ & - & - & - & - & - & - \\
\hline & 31 & 1 & $(1.3 \%)$ & - & - & - & - & - & - \\
\hline \multirow[t]{4}{*}{ Backed flake/blade } & 35 & - & - & 1 & $(0.8 \%)$ & - & - & - & - \\
\hline & 37 & - & - & 1 & $(0.8 \%)$ & - & - & - & - \\
\hline & 39 & - & - & 1 & $(0.8 \%)$ & - & - & - & - \\
\hline & 42 & - & - & 1 & $(0.8 \%)$ & - & - & - & - \\
\hline \multirow[t]{14}{*}{ Backed bladelet } & 45 & 3 & $(3.8 \%)$ & 9 & $(7.3 \%)$ & - & - & 3 & $(8.3 \%)$ \\
\hline & 46 & 5 & $(6.3 \%)$ & 4 & $(3.2 \%)$ & - & - & - & - \\
\hline & 47 & 1 & $(1.3 \%)$ & 3 & $(2.4 \%)$ & - & - & - & - \\
\hline & 49 & - & - & - & - & - & - & 1 & $(2.8 \%)$ \\
\hline & 50 & - & - & 1 & $(0.8 \%)$ & - & - & - & - \\
\hline & 51 & 2 & $(2.5 \%)$ & - & - & - & - & - & - \\
\hline & 52 & 1 & $(1.3 \%)$ & 2 & $(1.6 \%)$ & - & - & - & - \\
\hline & 55 & - & - & 2 & $(1.6 \%)$ & - & - & - & - \\
\hline & 56 & 4 & $(5.0 \%)$ & 5 & $(4.0 \%)$ & - & - & - & - \\
\hline & 58 & - & - & 1 & $(0.8 \%)$ & - & - & - & - \\
\hline & 62 & - & - & - & - & - & - & 1 & $(2.8 \%)$ \\
\hline & 66 & 15 & $(18.8 \%)$ & 14 & $(11.3 \%)$ & - & - & 5 & $(13.9 \%)$ \\
\hline & 68 & 1 & $(1.3 \%)$ & 4 & $(3.2 \%)$ & - & - & - & - \\
\hline & 71 & 1 & $(1.3 \%)$ & - & - & - & - & - & - \\
\hline \multirow[t]{4}{*}{ Notched } & 74 & 5 & $(6.3 \%)$ & 8 & $(6.5 \%)$ & - & - & 5 & $(13.9 \%)$ \\
\hline & 75 & 2 & $(2.5 \%)$ & 4 & $(3.2 \%)$ & - & - & 3 & $(8.3 \%)$ \\
\hline & 76 & 7 & $(8.8 \%)$ & 15 & $(12.1 \%)$ & 3 & $(20.0 \%)$ & 6 & $(16.7 \%)$ \\
\hline & 77 & 5 & $(6.3 \%)$ & 8 & $(6.5 \%)$ & - & - & 4 & $(11.1 \%)$ \\
\hline \multirow[t]{2}{*}{ End retouch } & 80 & 1 & $(1.3 \%)$ & 7 & $(5.6 \%)$ & 1 & $(6.7 \%)$ & - & - \\
\hline & 81 & - & - & 1 & $(0.8 \%)$ & - & - & - & - \\
\hline \multirow[t]{8}{*}{ Microlith } & 82 & 2 & $(2.5 \%)$ & 3 & $(2.4 \%)$ & 1 & $(6.7 \%)$ & - & - \\
\hline & 83 & - & - & 1 & $(0.8 \%)$ & 4 & $(26.7 \%)$ & 1 & $(2.8 \%)$ \\
\hline & 87 & - & - & 1 & $(0.8 \%)$ & - & - & - & - \\
\hline & 89 & - & - & 1 & $(0.8 \%)$ & - & - & - & - \\
\hline & 90 & - & - & 1 & $(0.8 \%)$ & - & - & 1 & $(2.8 \%)$ \\
\hline & 95 & - & - & 7 & $(5.6 \%)$ & - & - & 1 & $(2.8 \%)$ \\
\hline & 97 & 1 & $(1.3 \%)$ & 1 & $(0.8 \%)$ & - & - & - & - \\
\hline & 99 & 1 & $(1.3 \%)$ & - & - & - & - & - & - \\
\hline \multirow[t]{2}{*}{ Microburin } & 102 & 2 & $(2.5 \%)$ & - & - & - & - & - & - \\
\hline & 103 & 2 & $(2.5 \%)$ & - & - & - & - & - & - \\
\hline Divers & 104 & 3 & $(3.8 \%)$ & - & - & 1 & $(6.7 \%)$ & - & - \\
\hline
\end{tabular}


Table 7 (continued)

\begin{tabular}{|c|c|c|c|c|c|c|c|c|c|}
\hline \multicolumn{2}{|l|}{ Tixier type $n^{\circ}$} & \multicolumn{2}{|c|}{ Early EPI } & \multicolumn{2}{|c|}{ Late EPI } & \multicolumn{2}{|c|}{ ENC } & \multicolumn{2}{|c|}{ NEO } \\
\hline & 105 & 8 & $(10.0 \%)$ & 9 & $(7.3 \%)$ & 4 & $(26.7 \%)$ & 3 & $(8.3 \%)$ \\
\hline & 112 & - & - & 1 & $(0.8 \%)$ & - & - & - & - \\
\hline Total & & 80 & $(100 \%)$ & 124 & (100\%) & 15 & (100\%) & 36 & $(100 \%)$ \\
\hline
\end{tabular}

use-traces evident of wood processing; one has traces of treatment of non-ligneous plants, and three have traces indicative of processing mineral materials. The working on wood generates, depending on its hardness, abundant scars and a compact polishing with a voluminous appearance. In opposition, plant-related use-wears create extensive and compact polishing marks on the tool, and the processing of mineral materials causes an absolute rounding of the edge and many striations. Of course, for a group of tools, it was not possible to determine the processed material, but most of them were used for the treatment of soft materials, possibly meat or hide.
All three projectiles identified are made on backed bladelets (Fig. 9). The presence of fractures or striations of impact in the apical zone, or sometimes in the proximal area, suggests an insert at the end of the shaft. When the impact was rather intense, there was a repercussion that caused the breakage of the base of the projectile. The pieces intended for the butchering of animals are unretouched blades with sharp edges (Fig. 10: 1). It is difficult to assess their length because most are fractured. Nevertheless, some are close to $30 \mathrm{~mm}$ and there are others that surpassed this length. The four pieces used for the treatment of hide have usewear patterns indicative of scraping. They are two blades, one of them retouched, and two retouched
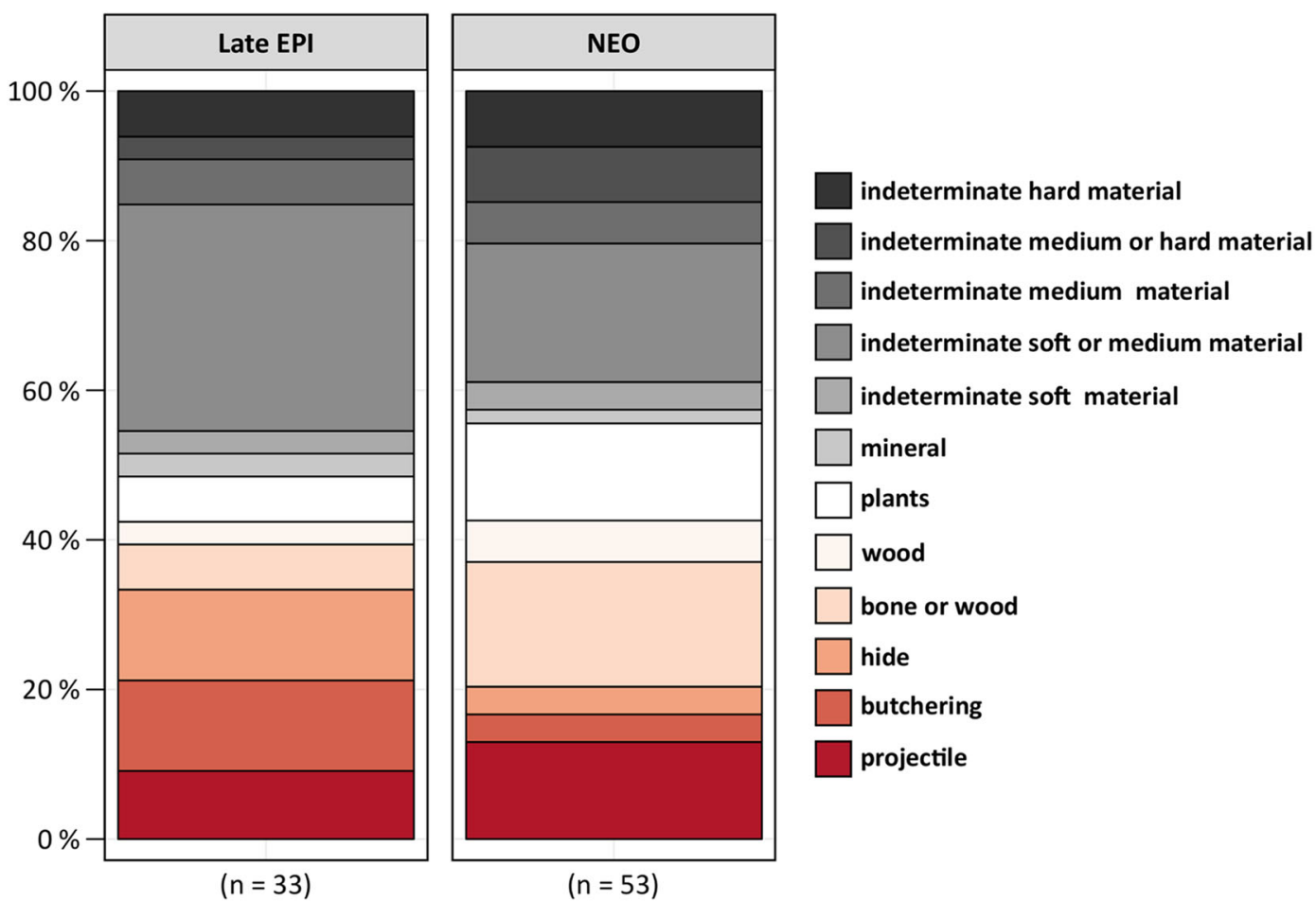

Fig. 8 Results of the use-wear analysis for the Late Epipalaeolithic and undated Neolithic assemblages at Ifri n'Etsedda (The absolute number in this graph exceeds the number of pieces with use-traces because several pieces were used to process more than one material) 
Fig. 9 Impact fractures of backed bladelets at Ifri n'Etsedda: 1 .

Early Epipalaeolithic (ID 6325);

2. Late Epipalaeolithic (ID 5371);

3. undated Neolithic (ID 5468).

Photos, $30 \times$ magnification, by $\mathrm{J}$.

F. Gibaja Bao

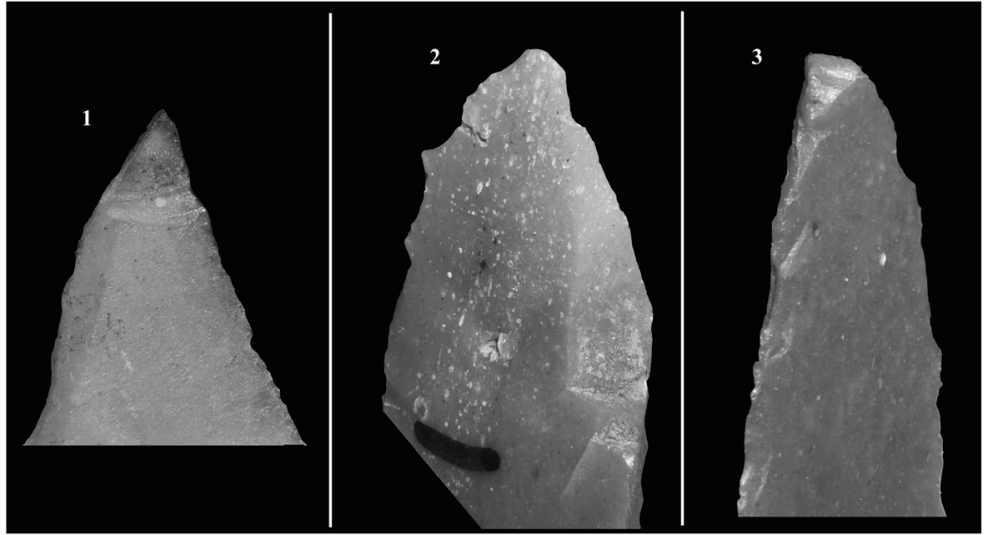

scrapers on flakes (Fig. 10: 2-3). In two cases, the degree and characteristics of the traces indicate that they were used to scrape dry hide. The processing of dry hide causes a strong rounding of the edge due to the abrasive impact of the hide, polishing with an
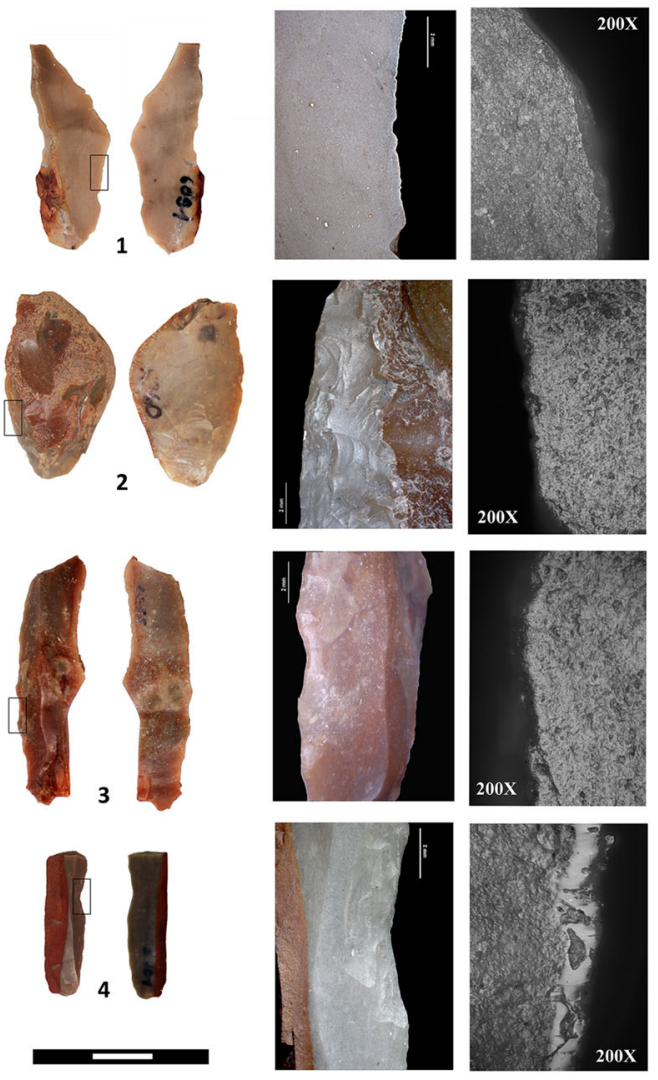

Fig. 10 Pieces with use-traces of the Late Epipalaeolithic (1-4) and the undated Neolithic (5-7) at Ifri n'Etsedda. Legends: 1. blade used for defleshing (ID 6091), 2. retouched flake used for scrapping of hide (ID 5360), 3. blade used for scrapping of dry hide (ID 5507), 4. notched blade used for scrapping of bone (ID open appearance, and striations that are arranged perpendicular to the edge. For the other two, the type of hide they were used on is not clear. It is worth mentioning that the same edge on one of the blades has traces related to two different activities:
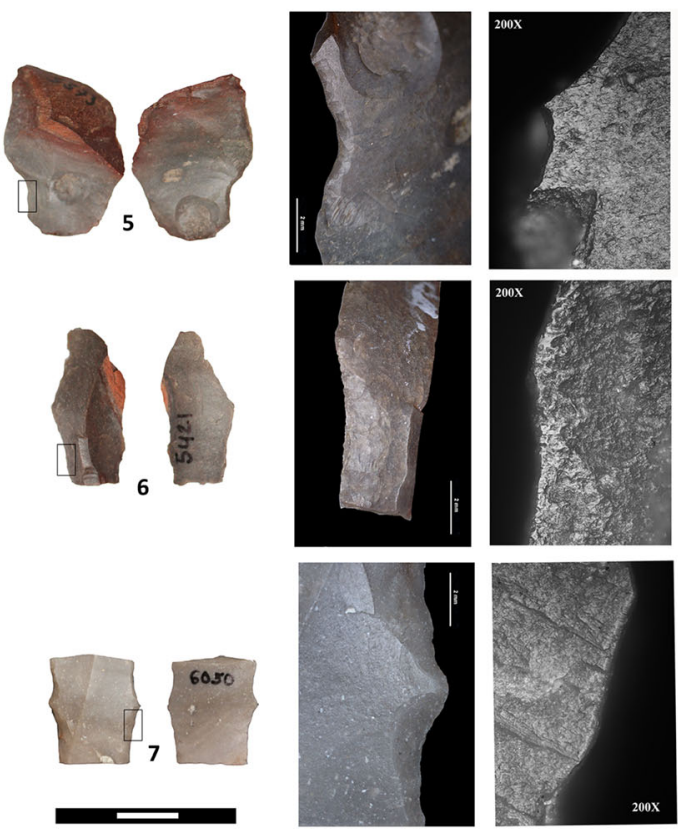

5101), 5. notched flake used for scrapping of wood (ID 5573), 6 . notched blade used for scrapping of wood (ID 5421), 7. retouched blade used for scrapping of a mineral material or maybe ostrich eggshell (ID 6050). Photos by J. F. Gibaja 
working hide and scraping non-woody plants. This shows that sometimes tools were not discarded after the first activity but kept for later and different use. This particular blade is extraordinarily large in size, being $43 \mathrm{~mm}$ in length, although it is a fragment.

Regarding the processing of animal bone materials, two notched blades were used in scraping tasks (Fig. 10: 4). A third piece, an unretouched flake, shows traces that have been generated as a result of scraping an animal bone or a hard wood. The analysis of the direction of the striations and the area where the scars, polishing, and striations are located reveals the movement patterns associated with the tool use. The activity zones have a somewhat reduced length, between 8 and $17 \mathrm{~mm}$, which suggests that they were used for the careful working of an object: a shaft, a handle, or a point. Two pieces have been used to process wood. Both are small retouched flakes with a length of $22 \mathrm{~mm}$ and $31 \mathrm{~mm}$, respectively. The original length may have been longer since they are broken in the distal part. The only piece used to process a mineral material is a small retouched flake of $17 \mathrm{~mm}$ in length. The activity zone belongs to a notch located on the right side. However, the traces are not diagnostic enough to make inferences on the nature of the processed mineral (stone, ceramics, etc.). Finally, we will argue that the pieces with poor diagnostic use-wear attributes may have been used to process soft materials, mainly of animal origin, and in cutting actions. Usually, unretouched blades and, to a lesser extent, unretouched flakes with sharp edges are represented in this group. There is also a group of tools with several notches, including a flake, an unretouched blade, a denticulated flake, and two retouched blades, which may have been used for processing very hard materials. As noted before, some use-wear traces and the state of conservation mitigated against a confident determination of the specific materials some of the tools were used to process. In some cases, the characteristics of the scars (shape, quantity, and distribution), the morphology of the polishing, the presence of striations, and the fact that the edges are rounded indicate at least the hardness of the worked material. Thus, for example, the cutting of soft materials usually produces small scars and hardly any polishing and rounding, while the working of hard materials generates a greater number of scars that are larger and superimposed and sometimes associated with compact polishing, striations on the inside of the polishing, and more or less a rounding of the edge.

Use-Wear Analysis of the Undated Neolithic Lithics

Of the 71 selected pieces, 14 were not used, five could not be analyzed because of their poor state of preservation, 40 showed use-traces, and 12 did not have criteria to confirm or deny if they were used (Fig. 8). As in the late Epipaleolithic, the pieces used for the acquisition and processing of animal materials stand out. However, certain differences can be detected. Firstly, there are more projectiles and tools for scraping of bone and wood than in the late Epipaleolithic assemblage. Secondly, even though it is a Neolithic level, the absence of tools intended for the cutting of non-woody plants, in particular cereals, is remarkable. To summarize, there are backed blades and asymmetrical geometrics that show impact fractures as a result of their use as projectiles (Fig. 9: 3). Usually, these are pieces in fairly good condition, with only small breaks in their distal part. Although they could have been reused, they were abandoned. The length of these pieces range between 22 and $35 \mathrm{~mm}$. As in the Late Epipaleolithic, some of the backed bladelets in the undated Neolithic context show no clear impact fractures. They were likely produced for hunting activities, but there are no diagnostic traces that can confirm this, a situation observed in many other Paleolithic, Mesolithic, and Neolithic deposits (Chesnaux 2013; Gassin and Gibaja 2016; Gibaja and Palomo 2004; Gonzales Urquijo and Ibáñez Estévez 1994). Two unretouched blades with very sharp edges were used for butchery tasks. One of these pieces is heavily fragmented and has a size of $13 \mathrm{~mm}$. Regarding the treatment of hide, an unretouched blade has been documented whose both sides were probably used to scrape dry hide. The visible strong abrasion on the surface of this piece supports the use of an additive with abrasive capacity. Likewise, a flake with lateral retouch shows on its left side traces related to the processing of two materials: hide and non-woody plants. That duality can be due to a process of reuse or the use of a vegetable substance as an abrasive for hide processing.

Furthermore, notched blades were used for scraping bones. Therefore, it is not surprising that bone tools such as needles were found at Ifri n'Etsedda. Some of these blades show four activity zones that correspond to four notches. Interestingly, one of the blades shows use-traces in a notch and on a small part of the unretouched side. Hence, it seems the notch was not used expressly to work 
this type of hard material, but first the edge was used without retouching and then, when it had lost effectiveness, it was revived by performing a notch. In this group, three more blades with notches that show traces related to the processing of bone or hard wood are noteworthy. Nevertheless, there are other tools, either made on flakes or blades, that were used only for processing wood (Fig. 10: 5-6). Any flake that has a sharp edge with a high angle is effective for scraping wood. They do not even have to be retouched. In the case of the blades, one is unretouched but shows an angle of $60^{\circ}$, and another is a notched blade, similar to the blades previously described. There is also a fragmented blade with both sides retouched that has been used for the scraping of hard mineral material. It is probable that ostrich eggshells were processed with this tool. The use-wear patterns - very compact polishing, very smooth appearance, and many striations - on this blade are the types of patterns one would expect from the ostrich eggshell processing (Fig. 10: 7). This suggestion is supported by numerous ostrich eggshell ornaments documented at the site (R. Hutter and S. Lehnig, pers. comm.). Finally, blades and flakes without retouch but with a sharp edge are among the tools for which the processed materials cannot be specified. However, we were able to determine that all of them were used to cut soft materials. In contrast, notched blades and flakes were usually used to process semi-hard or hard materials, although occasionally a concave unretouched but obtuse part of a blade or flake is selected as the activity zone.

\section{Discussion and Conclusion}

The analysis of the lithic assemblages of Ifri n'Etsedda rock shelter has revealed a great similarity between the Epipaleolithic and Neolithic occupations. Nevertheless, there are some differences, particularly for the late Early Neolithic (ENC) inventory. The main lithic raw material of all assemblages at Ifri n'Etsedda is the "Moulouya brown" subgroup (80-90\% of the tools), followed by the "Moulouya white" subgroup. The domination of this raw material is not surprising since the site is most easily accessed from the Oued Moulouya, the natural deposits of "Moulouya brown." Although all other types of raw material account only for a small proportion of the assemblages, they provide information on the land use or lithic exchange patterns. "Ain Zora" chert, which can be found at a distance of roughly $120 \mathrm{~km}$ to the southwest, is present in all the four occupation phases. Radiolarite as well as flint of "Exotic Fine Red" and "Exotic Fine Yellow" is only attested for the Epipaleolithic assemblages, while flint of "Oumazzine" is only present in the undated Neolithic inventory. Accordingly, all the four occupation levels show contacts further inland, and both the Early Epipaleolithic and undated Neolithic also had ties to the Mediterranean coast. It is worth highlighting that no radiolarite has been identified within the ENC assemblage, although the nearby and contemporaneous ENC site of El Zafrín (Rojo Guerra et al. 2010) is located on the outcrop of this raw material.

Further similarities between the Early and Late Epipaleolithic and the undated Neolithic can be seen in the method of blank production and target products. In contrast, the ENC lithic assemblage has differences that indicated a change in the method of blank production. The main target products in all four assemblages at Ifri n'Etsedda were non-cortical blades/bladelets ranging between $12 \mathrm{~mm}$ and $50 \mathrm{~mm}$ in length. Nevertheless, cortical blanks were also transformed into formal tools. Within the Epipaleolithic and Neolithic assemblages, the debitage direction is generally unidirectional, though orthogonal and irregular exploitations are also attested. These seem to highlight a frequent reorientation of cores to exploit the remaining volume of the previously unidirectional cores, a phenomenon recognized in the lithic assemblages of Ifri Oudadane (Linstädter et al. 2015). The orthogonal reduction is particularly well represented within the ENC assemblage. In addition, the ENC stands out regarding the detectable knapping features on blanks. For the Early and Late Epipaleolithic and the undated Neolithic, a hard hammer-stone was probably used for the core preparation and maintenance and a soft hammerstone or antler for the obtaining of blades/bladelets. Furthermore, the dimensions of blades seem to be more standardized than those of flakes, and no statistically relevant differences are observable between the assemblages. On the contrary, flakes of the ENC are longer and wider and suggest a change in production objectives. Although core maintenance products are attested in all four assemblages, they are not frequent, and it can be assumed that the small fist-sized pebbles of the Moulouya raw material group feature did not lend themselves to correction, due to minimal volume, whenever a knapping error (e.g., a hinge) occurred.

With respect to the Neolithic transition in the western Mediterranean, ${ }^{14} \mathrm{C}$ dates indicate that the first appearance of Neolithic features in southern Spain and northeast 
Morocco are contemporaneous (Linstädter et al. 2018). Although Neolithic settlers from the Tyrrhenian and southern French coasts likely brought the Neolithic innovation into the western Mediterranean, the simultaneous occurrence of these innovations and the diversity of manifestations point to an active role of Epipaleolithic societies in this process. We assume that these innovations were disseminated through already existing Epipaleolithic communication networks. The location where the initial contacts between local Epipaleolithic societies and Neolithic settlers took place and its duration cannot be specified yet. It may have been southern Spain, northeast Morocco, or both (Linstädter 2014; Linstädter et al. 2018).

Furthermore, it is important to note that all available data concerning food production within the Eastern Rif indicates that the use of domesticated species is limited (Linstädter et al. 2018). Although cultivation of cereals and legumes as well as animal husbandry is evident, the data points to a the ongoing importance of hunting and gathering (Linstädter et al. 2016; Morales et al. 2013). We assume that Neolithic innovations such as animal husbandry were adopted as part of a risk minimizing strategy within an increasingly semiarid environment. Regarding the subsistence economy, the concept of "Low Level Food Production" by Smith (2001) is useful for understanding this process. In contrast to the central European Neolithic transition (e.g., Linearbandkeramik), it seems that the Neolithic societies of the Eastern Rif did not exclusively rely on crop production and animal husbandry but combined these with hunting-gathering thereby creating an "in between" mode of subsistence (Smith 2001).

Supporting this hypothesis, the lithic industries of Ifri n'Etsedda and those of Ifri Oudadane show continuity in technology from the Early Epipaleolithic to the ENB. Additionally, the toolkits as well as the use-wear analysis do not indicate a significant change in activities conducted at Ifri n'Etsedda between the Late Epipaleolithic and Early Neolithic. Nevertheless, some typological differences between the Early and Late Epipaleolithic are recognizable from the Tixier-types of the backed bladelets. Overall, it is probable that the function of the site and land-use system of the Eastern Rif did not change significantly from the Epipaleolithic to the Early Neolithic. During the Epipaleolithic and from the point of view of the use-wear analysis and the recorded toolkits, Ifri n'Etsedda seems to be a site where not all kinds of activities were carried out, but only those related to the acquisition and processing of animal materials. This type of site is possibly a "residential hunting camp," that is, a site that has an intermediate function between the very specialized sites and the residential camps (Binford 1982). Residential hunting camps are characterized by multipurpose activities and had a longer duration of occupation in comparison to specialized sites. Hence, the function of the site of Ifri n'Etsedda is comparable with sites like the Epipaleolithic-Mesolithic deposits of Balma Margineda, Star Carr, Vaenget Nord, and Atxoste (Dumont 1988; Juel-Jensen and Petersen 1986; Perales 2015; Philibert 2002).

The Neolithic assemblages at Ifri n'Etsedda demonstrate the same activities as those of the Epipaleolithic, but the two have small differences in their lithic inventories. There was a greater frequency of tools for processing wood or bone during the Neolithic. The absence of pieces with use-traces of agricultural activities within the undated Neolithic, however, may be surprising, but this is consistent with the other early Neolithic sites in northern Morocco where no sickle elements have been documented. This circumstance could be explained on the one hand by the broad spectrum of the subsistence system and on the other hand by the fact that no lithic tools were probably used for crop harvesting. Instead, it is possible to harvest the whole stem or ear manually or with the help of wooden tools that have not survived in the archaeological deposits (Gibaja et al. 2012a; Gibaja et al. 2012b; Linstädter et al. 2015). Nevertheless, the pollen record as well as the presence of bones of domesticated ovicaprids during the Early Neolithic show that the groups who settled within that shelter did broaden their subsistence economy. In addition, the use of land snails as food during the Epipaleolithic continued into the Early Neolithic. Interestingly, snails gathering by herders is still common in the study area.

During the ENC, changes of the lithic technology occurred at Ifri n'Etsedda and coincided with the increasing aridity in the region (Linstädter et al. 2016; López et al. 2010; Zapata et al. 2013). At this time, the percentage of cereal pollen drops below 3\% at Ifri n'Etsedda indicating a change in subsistence. Probably, alterations in subsistence strategies caused the changes in lithic technology as different tools were needed for different activities. These changes have been observed in other parts of Morocco, all dating to the end of the seventh millennium calBP (Dougas 2010; El Idrissi 2012; Linstädter 2016), and are all linked to a climate deterioration (Linstädter et al. 2018). They are also linked to the expansion of cattle pastoralism (Martínez Sánchez et al. 2018; Smith 1993) as an adaption 
to the drier conditions at the end of the African Humid Period (Manning and Timpson 2014). While in the case of the Atlantic coast and Tangier peninsula, contacts to the interior of the continent are well documented through the occurrence of the so-called Ashakar ware (Martínez Sánchez et al. 2018); the ENC ceramic inventories of the Eastern Rif do not display continental influence but instead feature the cardial ware tradition, the earliest pottery of the western Mediterranean and parts of Atlantic Europe (Linstädter 2016).

In addition to the importance of Ifri n'Etsedda for a diachronic understanding of changes in lithic technology and subsistence between Epipaleolithic and Neolithic occupation phases, it is also possible to relate the site to the neighboring contemporaneous sites of the Eastern Rif. Differences and similarities are noticeable when comparing the lithic inventories at Ifri n'Etsedda with those of other sites of the region (Aschrafi 2010; Carvalho 2010; Gibaja et al. 2012b; Linstädter 2004; Linstädter et al. 2012). All Epipaleolithic and Neolithic sites of the Eastern Rif have shown a predominantly unidirectional mode of reduction in combination with irregular exploitation. Regarding the target products, however, the Ifri n'Etsedda inventories show differences. The main target products at Ifri n'Etsedda were non-cortical blades/bladelets, which were used for the production of armatures. In contrast, the target products of the Epipaleolithic and Early Neolithic (ENA, ENB) assemblages of Ifri Oudadane and the late Early Neolithic (ENC) assemblage of El Zafrìn were flakes and blades in approximately equal proportions (Gibaja et al. 2012b). There are two possible explanations for this circumstance: (1) the available raw material and its quality and shape of nodules or (2) the function of the site within the land use pattern. The latter interpretation is favored because the knapping properties of the "Black Silex" of the Ifri Oudadane assemblages and the radiolarite of the El Zafrìn site are similar to the "Moulouya brown" raw material. However, it must be mentioned that the target products could indeed depend on the raw material, as it is the case for the treatment of the "Moulouya brown" and "Moulouya white" raw material at Ifri n'Etsedda.

Ifri n'Etsedda was most probably a hunting camp, although from the Neolithic onwards, small-scale agricultural production and animal husbandry are also evident. The functions of the sites El Zafrìn and Ifri Oudadane within the land use pattern during the Epipaleolithic and Early Neolithic are different. The first site seems to be more of a residential site; hence, some kind of built structure has been documented, and the toolkit as well as the use-wear analysis indicates other activities than those performed at Ifri n'Etsedda. The second site could be classified as a "residential hunting camp" like Ifri n'Etsedda but with the focus on the exploitation of maritime resources and not on hunting prey (Roski 2018). Consequently, different tools and different target products were needed at the site of El Zafrìn and Ifri Oudadane.

Acknowledgments We would like to thank Josef Eiwanger, DAI (Deutsches Archäologisches Institut), Bonn, Germany, for long-term, amicable cooperative work and providing us with site data. We would also like to thank Jacqueline Broich for editing the French abstract. The authors are indebted to the two anonymous reviewers for their helpful and constructive comments on this manuscript. We also wish to thank Giulio Lucarini and Jörg Linstädter for the invitation to contribute to this volume.

Funding information Open Access funding provided by Projekt DEAL. The fieldwork and analysis of the lithic material have been funded by the Deutsche Forschungsgemeinschaft (DFG, German Research Foundation - Grant number 57444011) in the framework of the Collaborative Research Centre (CRC) 806 "Our way to Europe" project C2. The use-wear analysis was funded by the Spanish Ministry of Economy and Competitiveness (Grant number HAR2016-75201-P).

\section{Compliance with Ethical Standards}

Conflict of Interest The authors declare that they have no conflict of interest.

Open Access This article is licensed under a Creative Commons Attribution 4.0 International License, which permits use, sharing, adaptation, distribution and reproduction in any medium or format, as long as you give appropriate credit to the original author(s) and the source, provide a link to the Creative Commons licence, and indicate if changes were made. The images or other third party material in this article are included in the article's Creative Commons licence, unless indicated otherwise in a credit line to the material. If material is not included in the article's Creative Commons licence and your intended use is not permitted by statutory regulation or exceeds the permitted use, you will need to obtain permission directly from the copyright holder. To view a copy of this licence, visit http://creativecommons.org/licenses/by/4.0/.

\section{References}

Aschrafi, M. (2010). Die Fundstelle Taoungat 1 an der unteren Moulouya (Marokko). Unpublished Master's thesis. University of Cologne, Cologne. Institute of Prehistoric Archaeology.

Binford, L. R. (1982). The archaeology of place. Journal of Anthropological Archaeology, 1(1), 5-31.

Broich, M. (2013). Stratigrafie und räumliche Verteilung von Faunenresten der Ifri n'Etsedda, Nordost-Marokko. 
Unpublished Bachelor's thesis. Institute of Prehistoric Archaeology, University of Cologne, Cologne.

Carvalho, A. F. (2010). Tecnología y tipología de la industria lítica tallada del yacimiento neolítico de Zafrín (Islas Chafarina, Espana). In M. R. Guerra, R. G. Pena, J. A. Bellver Garrido, A. B. Nieto, G. Martínez de Lagrán, S. Gámez Gómez, \& C. Tejedor Rodríguez (Eds.), Zafrín. Un asentamiento del neolítico antiguo en las islas Chafarinas (Norte de África, España) (pp. 231-248). Valladolid: Univ. de Valladolid Secretariado de Publ. e Intercambio Editorial.

Chesnaux, L. (2013). Les microlithes du 62 rue Henry-Farman à Paris (15e arrondissement): Des flèches diverses pour différents gibiers abattus en des lieux distincts? In B. Valentin, B. Souffi, T. Ducrocq, J.-P. Fagnart, F. Séara, \& C. Verjux (Eds.), Palaeoethnographie du mésolithique. Recherches sur les habitats de plein air entre Loire et Neckar: actes de la table ronde internationale de Paris, 26 et 27 novembre 2010 (pp. 119-132). Paris: Société préhistorique française.

Dougas, J.-P. (2010). Le néolithique du Maroc, 25 ans de coopération franco-marocaine. Les nouvelles de l'archéologie, 120-121, 116-121.

Dumont, J. V. (1988). A microwear analysis of selected artefact types from the Mesolithic sites of Star Carr and Mount Sandel. Oxford: B.A.R.

El Idrissi, A. (2012). La céramique [El Harhoura 2]. In M. A. El Hajraoui, R. Nespoulet, \& A. Debénath (Eds.), Préhistoire de la région de Rabat-Témara (pp. 77-81). Rabat: Institut National des Sciences de l'Archéologie et du Patrimoine (INSAP).

Floss, H. (2012a). Bohrer. In H. Floss (Ed.), Steinartefakte vom Altpaläolithikum bis in die Neuzeit (pp. 477-480). Tübingen: Kerns.

Floss, H. (2012b). Grundbegriffe der Artefaktmorphologie und der Bruchmechanik. In H. Floss (Ed.), Steinartefakte vom Altpaläolithikum bis in die Neuzeit (pp. 117-132). Tübingen: Kerns.

Gassin, B. (1996). Evolution socio-économique dans le Chasséen de la grotte de l'Eglise supérieure (Var): Apport de l'analyse fonctionelle des industries lithiques. Monographie du CRA, 17. Paris: CNRS Editions.

Gassin, B., \& Gibaja, J. F. (2016). Analyse fonctionnelle de l'industrie lithique Capsienne de Kef Zoura D: premiers résultats. In D. Lubell (Ed.), Holocene prehistory in the Télidjène Basin, eastern Algeria. Capsian occupations at kef Zoura and Aïn Misteheyia (pp. 183-213). Oxford: Archaeopress.

Gibaja, J. F. (2003). Comunidades Neoliticas del Noreste de la Península ibérica. Una aproximación socio-económica a partir del estudio de la función de los útiles líticos. British Archaeological Reports, S1140. Oxford: Archaeopress.

Gibaja, J. F., \& Palomo, A. (2004). Geometrics used as projectile points: Economic, social and ideological implications for the Neolithic societies of the 5th-3rd Millennium Cal. BC in Northeast Iberia. Trabajos de Prehistoria, 61(1), 81-97.

Gibaja, J. F., Peña-Chocarro, L., Zapata, L., Ibáñez, J. J., Rodríguez, A., Carvalho, A., et al. (2012a). A los dos lados del Estrecho: las primeras evidencias de agricultura y el utillaje empleado en el sur de la Península Ibérica y el norte de Marruecos. Una perspectiva de futuro. In M. Borrell, F. Borrell, J. Bosch, X. Clop, \& M. Molist (Eds.), Xarxes al Neolític. Circulació $i$ intercanvi de matèries, productes $i$ idees a la Mediterrània occidental (VII-III millenni aC).
Actes del Congrés Internacional (pp. 87-94). Gavà: Institut Municipal de Gestió del Patrimoni Cultural i Natural.

Gibaja, J. F., Carvalho, A. F., Rojo, M., Garrido, R., \& García, I. (2012b). Production and subsistence strategies at El Zafrín (Chafarinas Islands, Spain). New data for the early Neolithic of north-West Africa. Journal of Archaeological Science, 39(10), 3095-3104.

Gonzales Urquijo, J. E., \& Ibáñez Estévez, J. J. (1994). Metodologia de analisis funcional de instrumentos tallados en silex. Bilbao: Universidad de Deusto.

Götz, S. (2016). Herkunftsanalyse der Steinartefakte aus der Ifri El Baroud. Unpublished Master's thesis. Eberhard-Karls Universität, Tübingen.

Hahn, J. (1993). Erkennen und Bestimmen von Stein- und Knochenartefakten. Einführung in die Artefaktmorphologie. Tübingen: Verl. Archaeologica Venatoria.

Hundsdörfer, H. (2014). Terrestrische Mollusken der Ifri n'Etsedda (NO-Morocco) als Nahrungsressource und Umweltindikator. Unpublished Bachelor's thesis. Institute of Prehistoric Archaeology, University of Cologne, Cologne.

Hutterer, R., Linstädter, J., Eiwanger, J., \& Mikdad, A. (2014). Human manipulation of terrestrial gastropods in Neolithic culture groups of NE Morocco. Quaternary International, 320, 83-91.

Ibouhouten, H., Zielhofer, C., Mahjoubi, R., Kamel, S., Linstädter, J., Mikdad, A., et al. (2010). Archives alluviales holocènes et occupation humaine en Basse Moulouya (Maroc nord-oriental). Geomorphologie., 16(1), 41-56.

Jarvis A., Reuter, H. I., Nelson, A., \& Guevara, E. (2008). Holefilled seamless SRTM data V4, International Centre for Tropical Agriculture (CIAT). available from http://srtm.csi. cgiar.org. Accessed August 2018.

Juel-Jensen, H., \& Petersen, E. (1986). A functional study of lithics from Vaenget Nord a mesolithic site at Vedbaek, N.E. Sjaelland. Journal of Danish Archaeology, 4, 40-51.

Le Brun-Ricalens, F. (2012). Ausgesplitterte Stücke. Kenntnisstand nach einem Jahrhundert Forschung. In $\mathrm{H}$. Floss (Ed.), Steinartefakte vom Altpaläolithikum bis in die Neuzeit (pp. 439-459). Tübingen: Kerns.

Linstädter, J. (2004). Zum Frühneolithikum des westlichen Mittelmeerraums. Die Keramik der Fundstelle Hassi Ouenzga. Aachen: Linden-Soft.

Linstädter, J. (2014). Die früh- und mittelholozäne Besiedlungsgeschichte und der Beginn der produzierenden Wirtschaftsweise im Nordosten Marokkos. Mitteilungen der Gesellschaft für Urgeschichte, 23, 173-223.

Linstädter, J. (2016). Climate induced mobility and the missing middle Neolithic of Morocco. In M. Reindel, K. Bartl, F. Lüth, \& N. Benecke (Eds.), Palaeoenvironment and the development of early settlements. Proceedings of the International Conferences: Palaeoenvironment and the Development of Early Societies (Sanliurfa/Turkey, 5-7 October 2012) (pp. 63-80). Rahden: VML.

Linstädter, J., \& Kehl, M. (2012). The Holocene archaeological sequence and sedimentological processes at Ifri Oudadane, NE Morocco. Journal of Archaeological Science, 39(10), 3306-3323.

Linstädter, J., \& Wagner, G. (2013). The early Neolithic pottery of Ifri Oudadane, NE Morocco: Qualitative and quantitative evidence. Journal of African Archaeology, 11(2), 155-196. 
Linstädter, J., Aschrafi, M., Ibouhouten, H., Zielhofer, C., Bussmann, J., Deckers, K., et al. (2012). Flussarchäologie der Moulouya-Hochflutebene, NO-Marokko. Madrider Mitteilungen, 53, 1-84.

Linstädter, J., Wagner, G., Broich, M., Gibaja Bao, J. F., \& Rodríguez Rodríguez, A. (2015). Neolithic transition and lithic technology: The Epipalaeolithic and early Neolithic assemblages of Ifri Oudadane, NE-Morocco. Quartär, 62, 155-184.

Linstädter, J., Kehl, M., Broich, M., \& López-Sáez, J. A. (2016). Chronostratigraphy, site formation processes and pollen record of Ifri n'Etsedda, NE Morocco. Quaternary International, 410, 6-29.

Linstädter, J., Broich, M., \& Weninger, B. (2018). Defining the early Neolithic of the eastern Rif, Morocco - Spatial distribution, chronological framework and impact of environmental changes. Quaternary International, 472, 272-282.

López, J. A., López, P., \& López, L. (2010). Paleoambiente de las Islas Chafarinas durante el neolítico antiguo: Análisis polínicos en el yacimiento arqueológico de Zafrín (Isla del Congreso). In M. R. Guerra, R. G. Pena, J. A. B. Garrido, A. B. Nieto, Í. G. M. de Lagrán, S. G. Gómez, \& C. T. Rodríguez (Eds.), Zafrín. Un asentamiento del neolítico antiguo en las islas Chafarinas (Norte de África, España) (pp. 165-175). Valladolid: Univ. de Valladolid Secretariado de Publ. e Intercambio Editorial.

Manen, C., Martínez de Lagrán, Í. G., \& López-Montalvo, E. (2018). The neolithisation of the Western Mediterranean: New debates about an old issue. Quaternary International, $472,169-171$.

Manning, K., \& Timpson, A. (2014). The demographic response to Holocene climate change in the Sahara. Quaternary Science Reviews, 101, 28-35.

Martínez Sánchez, R. M., Vera Rodríguez, J. C., Peña-Chocarro, L., Bokbot, Y., Pérez Jordà, G., \& Pardo-Gordó, S. (2018). The Middle Neolithic of Morocco's North-Western Atlantic Strip: New evidence from the El-Khil caves (Tangier). African Archaeological Review, 35(3), 417-442.

Morales, J., Pérez-Jordà, G., Peña-Chocarro, L., Zapata, L., RuízAlonso, M., López-Sáez, J. A., \& Linstädter, J. (2013). The origins of agriculture in North-West Africa: Macro-botanical remains from Epipalaeolithic and Early Neolithic levels of Ifri Oudadane (Morocco). Journal of Archaeological Science, 40(6), 2659-2669.

Moser, J. (2003). La Grotte d'Ifri n'Ammar. Tome 1: L'Ibéromaurusien. Köln: Linden Soft.

Nami, M., \& Moser, J. (2010). La Grotte d'Ifri n'Ammar. Tome 2: Le Paléolithique Moyen. Wiesbaden: Reichert.

Pasda, C. (2012). Lateralretuschen. In H. Floss (Ed.), Steinartefakte vom Altpaläolithikum bis in die Neuzeit (pp. 467-476). Tübingen: Kerns.

Pelegrin, J. (2000). Les techniques de débitage laminaire au Tardiglaciaire: Critères de diagnose et quelques réflexions. In B. Valentin, P. Bodu, \& M. Christensen (Eds.), L'Europe centrale et septentrionale au tardiglaciaire. Actes de la tableronde internationale de Nemours (pp. 73-86). Nemours: Éd. APRAIF.

Perales, U. (2015). Traceología de la industria lítica de Atxoste (Álava): Aproximación a la gestión económico-social del asentamiento en el final del mesolítico e inicios del neolítico. Ph.D. dissertation. Universidad de País Vasco, Lejona.
Philibert, S. (2002). Les derniers "sauvages". Territoires économiques et systèmes techno-fonctionnels mésolithiques. Oxford: Hadrian Books.

Plisson, H. (1985). Etude fonctionnelle d'outillages lithiques préhistoriques par l'analyse des micro-usures: recherche méthodologique et archéologique. Ph.D. dissertation. Université de Paris I. Panthéon Sorbonne.

Potì, A. (2019). Technical change and environmental change in the Iberomaurusian: A case study from Ifri El Baroud, Morocco. Mettmann: Neanderthal Museum.

Roberts, N., Woodbridge, J., Palmisano, A., Bevan, A., Fyfe, R., \& Shennan, S. (2019). Mediterranean landscape change during the Holocene: Synthesis, comparison and regional trends in population, land cover and climate. The Holocene, 29(5), 923-937.

Rojo Guerra, M., Garrido Pena, R., Bellver Garrido, J. A., Bravo Nieto, A., García Martínez de Lagrán, Í., Gámez Gómez, S., \& Tejedor Rodríguez, C. (Eds.). (2010). Zafrín. Un asentamiento del neolitico antiguo en las islas Chafarinas (Norte de África, España). Valladolid: Univ. de Valladolid Secretariado de Publ. e Intercambio Editorial.

Roski, N. (2018). Maritime fishing during the transition from the Epipaleolithic and early Neolithic at Abri Ifri Oudadane, NE Morocco. Unpublished Master's thesis. Eberhard-Karls Universität, Tübingen.

Schön, W. (2012). Veränderungen an Steinartefakten durch Wind, Hitze und Frost. In H. Floss (Ed.), Steinartefakte vom Altpaläolithikum bis in die Neuzeit (pp. 101-104). Tübingen: Kerns.

Sheppard, P. (2016). The lithic assemblage. In D. Lubell (Ed.), Holocene prehistory in the Télidjène Basin, eastern Algeria. Capsian occupations at Kef Zoura and Aïn Misteheyia (pp. 41-94). Oxford: Archaeopress.

Smith, A. B. (1993). Origins and spread of pastoralism in Africa. Nomadic Peoples, 32, 91-105.

Smith, B. D. (2001). Low-level food production. Journal of Archaeological Research, 9(1), 1-43.

Stempfle, S., Linstädter, J., Nickel, K. G., Mikdad, A., \& Schmidt, P. (2018). Early Neolithic pottery of Ifri n'Etsedda, NEMorocco: Raw materials and fabrication techniques. Journal of Archaeological Science: Reports, 19, 200-212.

Tixier, J. (1963). Typologie de l'épipaléolithique du Maghreb. Paris: Arts et Métiers Graphiques.

Van Gijn, A. (1989). The wear and tear of Flint: Principles of functional analysis applied to Dutch Neolithic assemblages. Analecta Praehistorica Leidensia 22. Leiden: Institute of Prehistory.

Zapata, L., López-Sáez, J. A., Ruiz-Alonso, M., Linstädter, J., Pérez-Jordà, G., Morales, J., et al. (2013). Holocene environmental change and human impact in NE Morocco: Palaeobotanical evidence from Ifri Oudadane. The Holocene, 23(9), 1286-1296.

Zielhofer, C., Köhler, A., Mischke, S., Benkaddour, A., Mikdad, A., \& Fletcher, W. J. (2019). Western Mediterranean hydroclimatic consequences of Holocene ice-rafted debris (Bond) events. Climate of the Past, 15(2), 463-475.

Publisher's Note Springer Nature remains neutral with regard to jurisdictional claims in published maps and institutional affiliations. 